RELATIONS BETWEEN WARM SPRINGS AND

GEOLOGY DELINEATED BY SIDE-LOOKING AIRBORNE-RADAR

IMAGERY IN EASTERN WEST VIRGINIA

by Peter Lessing, W. A. Hobba, Jr., S. L. Dean, and B. R. Kulander

UNITED STATES GEOLOGICAL SURVEY

Water-Resources Investigations Report 88-4096

Prepared in cooperation with the

WEST VIRGINIA GEOLOGICAL AND ECONOMIC SURVEY

Morgantown, West Virginia

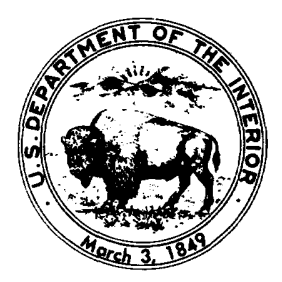

1991 


\section{DEPARTMENT OF THE INTERIOR}

MANUEL LUJAN, JR., Secretary

U.S. GEOLOGICAL SURVEY

Dallas L. Peck, Director

For additional information write to:

Copies of this report can be purchased from:

District Chief

U.S. Geological Survey

603 Morris Street

Charleston, WV 25301
U. S. Geological Survey

Books and Open-File Reports Section

Box 25425, Federal Center, Bldg. 810

Denver, CO 80225 


\section{CONTENTS}

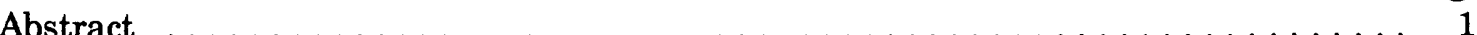

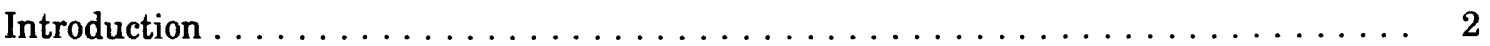

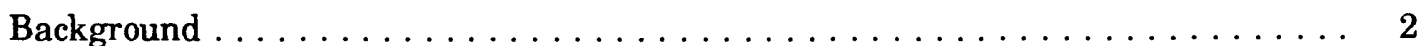

Purpose and scope ............................ 2

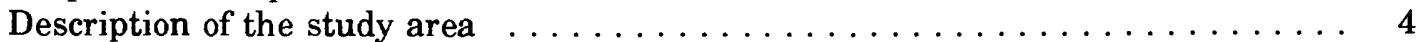

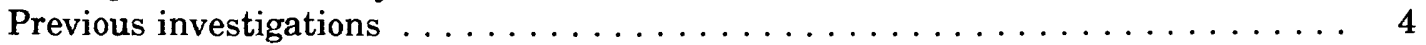

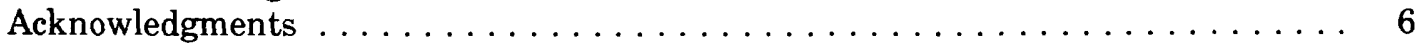

Description of side-looking airborne radar $\ldots \ldots \ldots \ldots \ldots \ldots \ldots \ldots \ldots \ldots$

Detection of lineaments by side-looking airborne-radar and

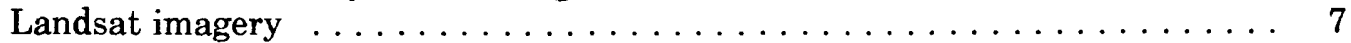

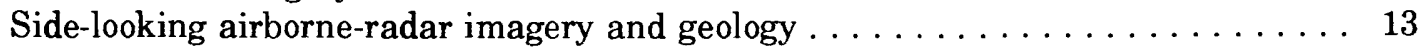

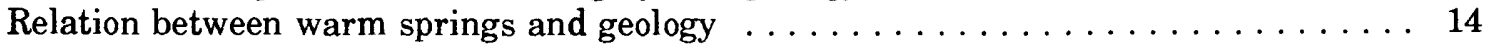

Berkeley Springs and Hancock Station Spring area . . . . . . . . . . . . 14

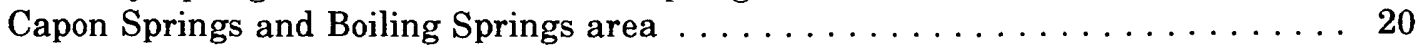

Minnehaha, Curry, McCarty, and Dunmore Springs area .......... 28

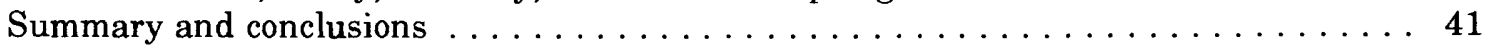

References ................................. 42

\section{ILLUSTRATIONS}

Figures 1-2. Map showing:

1. Counties, river basins, warm springs, and side-looking

airborne radar image quadrangles of eastern West Virginia $\ldots \ldots \ldots \ldots 3$

2. Physiographic provinces, warm springs, anticlinoria,

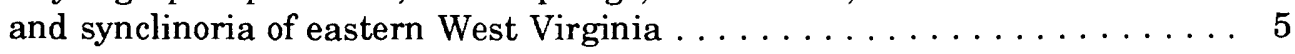

3. Diagram showing general conditions of side-looking

airborne-radar imagery acquisition $\ldots \ldots \ldots \ldots \ldots \ldots$

4-6. Side-looking airborne-radar images showing:

4. Lineaments in Berkeley Springs and Hancock Station Spring area . . . . . 9

5. Lineaments in Capon Springs and Boiling Springs area . . . . . . . . 10

6. Lineaments in Minnehaha, Curry, McCarty, and Dunmore Springs area . . . . . . . . . . . . . . . . . . . . . . . . . . 11

Figure 7. Rose diagrams of cumulative length of lineaments mapped on side-looking airborne-radar images and cumulative frequency of fracture trends measured in the rocks at selected warm-spring areas . . . . . 12

8-9. Geologic map of:

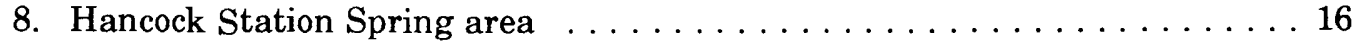

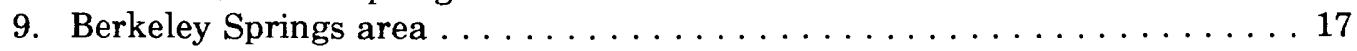

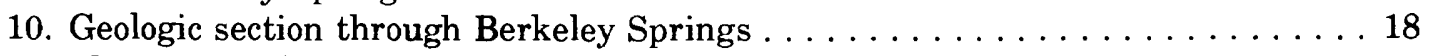

11. Photograph showing Capon Springs and near-vertical Oriskany

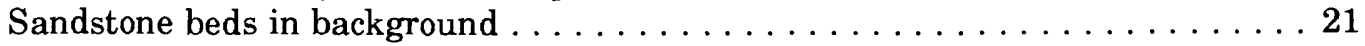

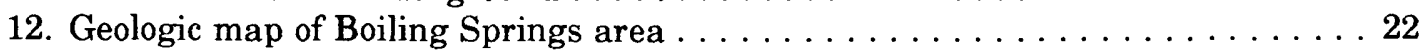

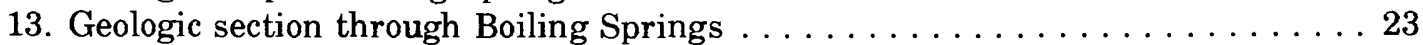

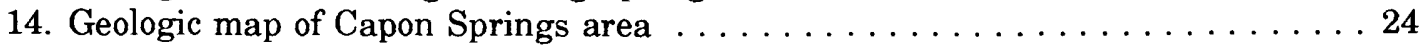

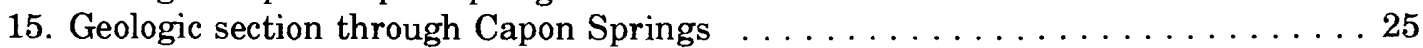

16. Geologic section through Capon Springs showing joints, thrust fault, vertical fracture zone, and possible

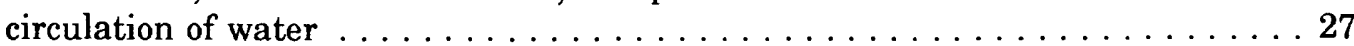


17. Geologic map of Curry and Minnehaha Springs area . . . . . . . . . 29

18. Geologic section through Minnehaha and Curry Springs . . . . . . . . . 30

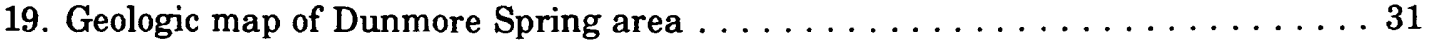

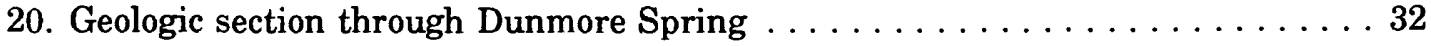

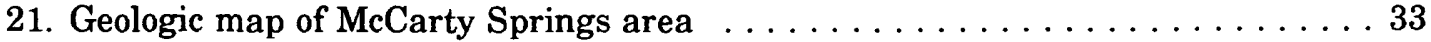

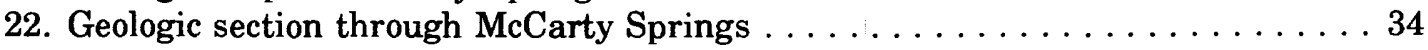

23-27. Photograph showing:

23. "Little Arch" (Devil's Backbone) anticline in

Tuscarora Sandstone, Route 39, Minnehaha Springs area . . . . . . . . 35

24. Fractures in horizontal Tuscarora Sandstone, Route 39,

Minnehaha Springs area. . . . . . . . . . . . . . . . 37

25. Fractures in Oriskany Sandstone, Route 39, Minnehaha Springs. . . . . . . 38

26. Fractures in limestones of the Helderberg Group, Route

28/92, Knapp Creek, 1.0 mile southwest of Frost, West Virginia. . . . . . 39

27. Fractures in Marcellus Shale, Route 28/92, 5.5 miles north of

Minnehaha Springs.

\section{TABLE}

Table 1. Selected geological and hydrological characteristics at eight warm springs in eastern West Virginia

\section{CONVERSION FACTORS AND ABBREVIATIONS}

For use of readers who prefer to use metric (International System) units, rather than the inch-pound terms used in this report, the following conversion factors may be used:

\section{Multiply Inch-Pound Unit}

inch (in.)

foot $(\mathrm{ft})$

foot per day $(\mathrm{ft} / \mathrm{d})$

gallon (gal)

gallon per minute (gal/min)

foot squared per day $\left(\mathrm{ft}^{2} / \mathrm{d}\right)$

degrees Fahrenheit $\left({ }^{\circ} \mathrm{F}\right)$
By

25.4

0.3048

0.3048

3.785

0.06308

0.09290

$0.555\left({ }^{\circ} \mathrm{F}-32\right)$

\section{To Obtain Metric Unit}

millimeter $(\mathrm{mm})$

meter $(\mathrm{m})$

meter per day $(\mathrm{m} / \mathrm{d})$

liter $(\mathrm{L})$

liters per second $(\mathrm{L} / \mathrm{s})$

meters squared per day $\left(\mathrm{m}^{2} / \mathrm{d}\right)$

degrees Celsius $\left({ }^{\circ} \mathrm{C}\right)$

Sea level: In this report "sea level" refers to the National Geodetic Vertical Datum of 1929 (NGVD of 1929)-a geodetic datum derived from a general adjustment of the first-order level nets of both the United States and Canada, formerly called "sea level datum of 1929." 


\title{
RELATIONS BETWEEN WARM SPRINGS AND GEOLOGY DELINEATED BY SIDE-LOOKING AIRBORNE-RADAR IMAGERY IN EASTERN WEST VIRGINIA
}

\author{
By Peter Lessing', W. A. Hobba, Jr.', S. L. Dean ${ }^{\text {, }}$, and B. R. Kulander
}

\begin{abstract}
Side-looking airborne-radar images of eastern West Virginia were used to delineate geologic structures and lineaments in the vicinity of eight warm springs that range in temperature from $15.3^{\circ}$ to $22.2^{\circ}$ Celsius. All of the warm springs are within regional anticlinoria, on flanks or noses of folds, and in or near outcrops of the Oriskany Sandstone of Middle Devonian age. The lineaments detected from the radar images range in length from less than one mile to tens of miles and cut through or lie near all of the springs. The lineaments trending $\mathbf{N}$. $30-75^{\circ} \mathrm{W}$. correspond to systematic fractures that trend N. 40-45 $\mathrm{W}$., but lineaments trending N. 60-75 E. do not correspond to systematic fractures that trend N. $40-45^{\circ} \mathrm{E}$.

Recent field mapping and the radar images, together with black-and-white and color infrared aerial photographs, and chemical analyses of spring-water samples have provided data for the interpretation of the geological and structural control of the area's warm springs. Tritium content of spring-water samples suggests that water that circulated as deep as 1,800 feet below the surface represents 60 to 98 percent of the warm- spring discharges. The depth of circulation seems to be controlled by thrust faults on the forelimbs of folds and back thrusts on the backlimbs of folds.
\end{abstract}

\footnotetext{
1 West Virginia Geological and Economic Survey, Morgantown, West Virginia.

${ }^{2}$ U.S. Geological Survey, Morgantown, West Virginia.

${ }^{3}$ Department of Geology, University of Toledo, Toledo, Ohio

${ }^{4}$ Department of Geological Sciences, Wright State University, Dayton, Ohio.
} 


\section{INTRODUCTION}

\section{Background}

Erskine (1948) and Waring (1965) reported 22 warm springs-water temperatures above $15.5^{\circ} \mathrm{C}$-along the eastern boundary of West Virginia. A later study of warm springs in nine areas in the Appalachians from Georgia to New York (Hobba and others, 1979) indicated that the water discharging from the warm springs was deep circulating water heated by "normal" geothermal heat flow. They determined that where the geologic structure is relatively uncomplicated, ground water discharging from warm springs has probably circulated to great depths in sandstone or limestone rocks roughly parallel to the strike of the bedding, and has moved rapidly upward where a fault or faults cross the bedding.

In 1982, side-looking airborne radar (SLAR) images were acquired for some parts of the contiguous United States and Alaska. The SLAR images were processed and made available in $1^{\circ}$ by $2^{\circ}$ sheets at a scale of 1:250,000. Two of these quadrangles, Charlottesville and Cumberland, covered the eastern part of West Virginia, including the warm springs areas (fig. 1).

This study was undertaken, in cooperation with the West Virginia Geologic and Economic Survey, to determine if SLAR imagery could be used to map lineaments, geologic structure, and possibly lithology, in the vicinity of the numerous warm springs in eastern West Virginia (fig. 1).

\section{Purpose and Scope}

The purpose of this report is to document the utility of SLAR imagery for mapping lineaments and geologic structure in the vicinity of warm springs in eastern West Virginia. This information was used in conjunction with geologic maps and water-quality analyses to define the geologic setting and hydrologic regime in the vicinity of the springs.

Several approaches were used to accomplish the purpose of the study. SLAR imagery was used to map lineaments in the study area. These lineaments then were compared to previously mapped lineaments using Landsat images. In areas where the geology was poorly defined, geology and fractures were mapped (Kulander and Dean, 1986). These maps were used to determine if there was a relation between fracture orientation and the location and orientation of lineaments detected on SLAR images. Well data and proprietary seismic data were used to construct geologic sections (Kulander and Dean, 1986). Water samples collected from the warm springs and from some cold springs were analyzed for common chemical constituents and for some stable isotopes. The geologic sections and water chemistry provided clues to the subsurface geology, hydrology, and the depth of water circulation along lineaments.

Early in the study, 19 of the 22 warm springs reported by Erskine (1948) and Waring (1965) were revisited. The temperatures of 11 of the 19 springs visited were below $13.5^{\circ} \mathrm{C}$, indicating that they were not warm. Most of these non-warm springs are located adjacent to streams that are in valleys underlain by limestone. The temperature measurements reported by Erskine (1948) were made in late summer and early fall when stream temperatures are highest. Thus, these 11 springs are in places where shallow circulating water emerges after having entered the rock as surface water at some upstream point (probably through cavernous limestone). The temperature and quality of the water from these springs closely reflects the temperature and quality of the surface streams supplying water to them.

Three of the 22 springs were not visited because either the available data indicated that they were not warm or the spring could not be located. One of these springs in Hampshire

County was not visited because it is located high on a hillside and the temperature of the water was measured in July 1945 about 1,000 feet downstream from the spring; thus, the 


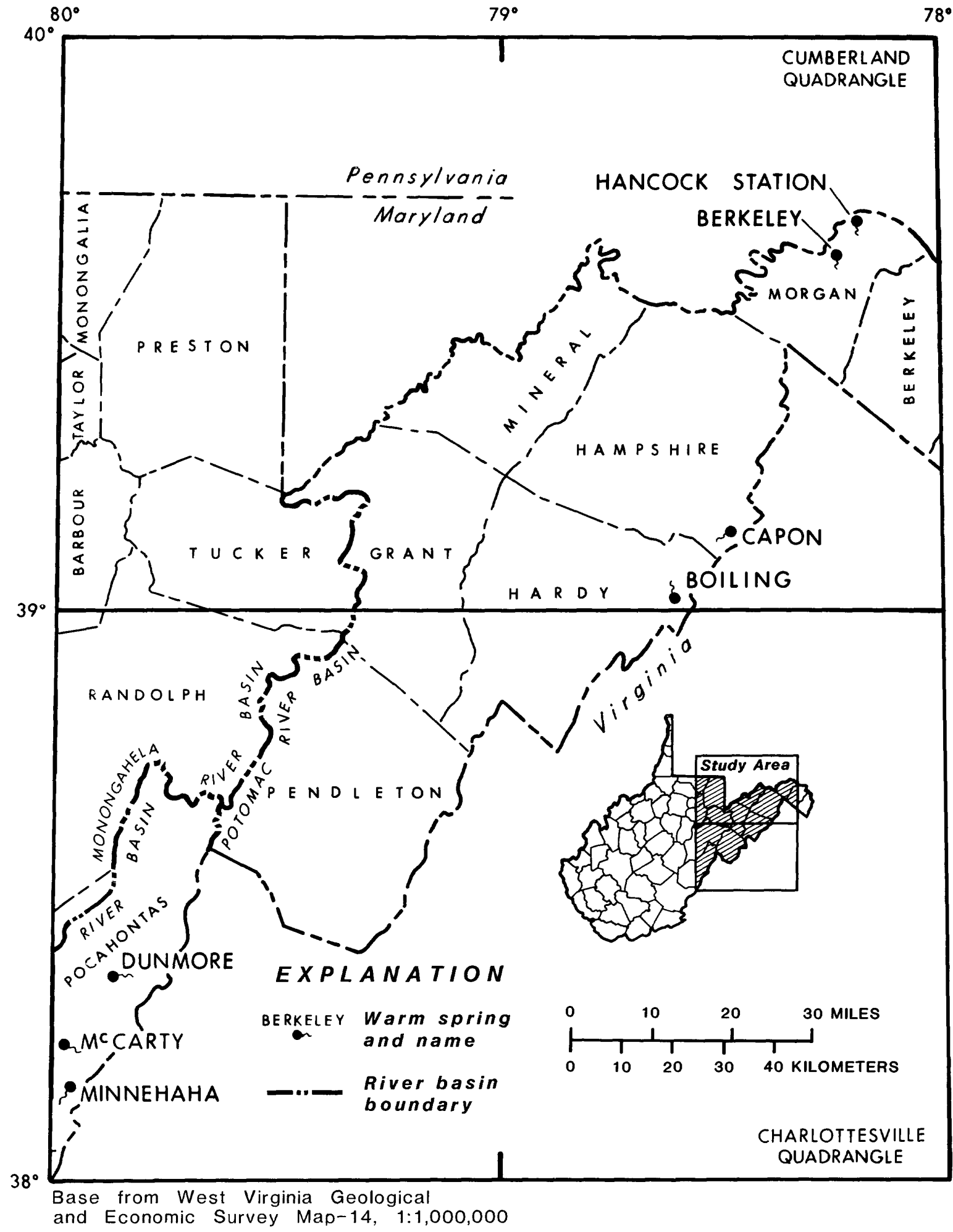

Figure 1. Map showing counties, river basins, warm springs, and side-looking airborne radar image quadrangles of eastern West Virginia. 
water was probably warmed by solar heat as it moved over the ground. Two springs in Jefferson County could not be located-North Branch of Walker Spring (Erskine, 1948, p. 38), and Shannondale Blue Sulphur Spring (Price and others, 1936, p. 71-72). It was assumed that the temperature reported by Erskine for Walker Spring was measured in a stream fed by the spring. Thus, solar heating probably had occurred. Shannondale Blue Sulphur Spring is on an abandoned farm and could not be located. However, the reported small discharge (1 gallon per minute (gal/min)) suggests that it is not warm, but the high mineral content $(2,570$ milligrams per liter) (Price and others, 1936, p. 71-72) suggests that it is discharging slow moving deepcirculating water.

After ascertaining that 8 of the reported 22 warm springs actually were warm springs, then mapping and sampling efforts were concentrated in the areas of these springs.

\section{Description of the Study Area}

This investigation covers parts of the Cumberland and Charlottesville (1:250,000 scale) $1^{\circ}$ latitude by $2^{\circ}$ longitude quadrangles in eastern West Virginia (fig. 1). Most of the study area is in the Valley and Ridge physiographic province, however, the western part of the area is in the Appalachian Plateau physiographic province (fig. 2). The rocks in the area range in age from Cambrian to Mississippian. The older Cambrian rocks are concentrated to the east in the Great Valley part of the Valley and Ridge physiographic province. The younger Mississippian rocks are concentrated west of the Allegheny Front in the Appalachian Plateau physiographic province.

The Valley and Ridge physiographic province lies east of the Allegheny Front and consists of northeast-trending mountains and valleys that reflect erosion of anticlines and synclines. In addition, there are numerous minor folds and thrust, splay, and back-thrust faults.

The Valley and Ridge part of the study area lies entirely in the Potomac River basin, where the land-surface altitude ranges from about 250 to 4,500 feet above sea level. Trellis drainage patterns predominate, and average annual precipitation ranges from 32 to 60 inches (Hobba and others, 1972, p. 10).

The Appalachian Plateau, which lies west of the Allegheny Front, generally is underlain by gently folded Mississippian and Pennsylvanian age shale, sandstone, limestone, and coal formations. Typically, folds have long wave lengths (10-20 miles) and show little structural complexity near the surface. However, in the study area, the rocks within the Browns Mountain Anticlinorium (fig. 2) are highly folded and faulted at the surface. The exposed rocks in the anticlinorium range in age from Upper Ordovician to Upper Devonian, whereas, further west, younger rocks of Lower Mississippian to Upper Pennsylvanian age are exposed.

In the Appalachian Plateau part of the study area, the land-surface altitude ranges from 790 to 4,860 feet above sea level, and lies in the Monongahela, New, and Potomac river basins. Dendritic and trellis drainage patterns occur, and average annual precipitation ranges from 45 to 60 inches (Friel and others, 1967, p. 12; Clark and others, 1976).

\section{Previous Investigations}

Numerous geological reports are available for eastern West Virginia; such as reports by Tilton and others (1927), and theses by Dyckes (1964), Martin (1964), Minke (1964), Kulander (1968), Nock (1968), and Geiser (1970). A report by Kulander and Dean (1972) deals mainly with geophysical and geological interpretations of the Minnehaha Springs area (see also Kulander and Dean, 1978; and Kulander and others, 1984). County reports by Grimsley (1916) and Price (1929) are primarily geological reports, but they also contain historical information and chemical analyses on some of the area's warm springs.

The geologic map of West Virginia by Cardwell and others (1968) and geologic reports for parts of Virginia by Butts and Edmondson (1966), and Young and Rader (1974) were helpful 


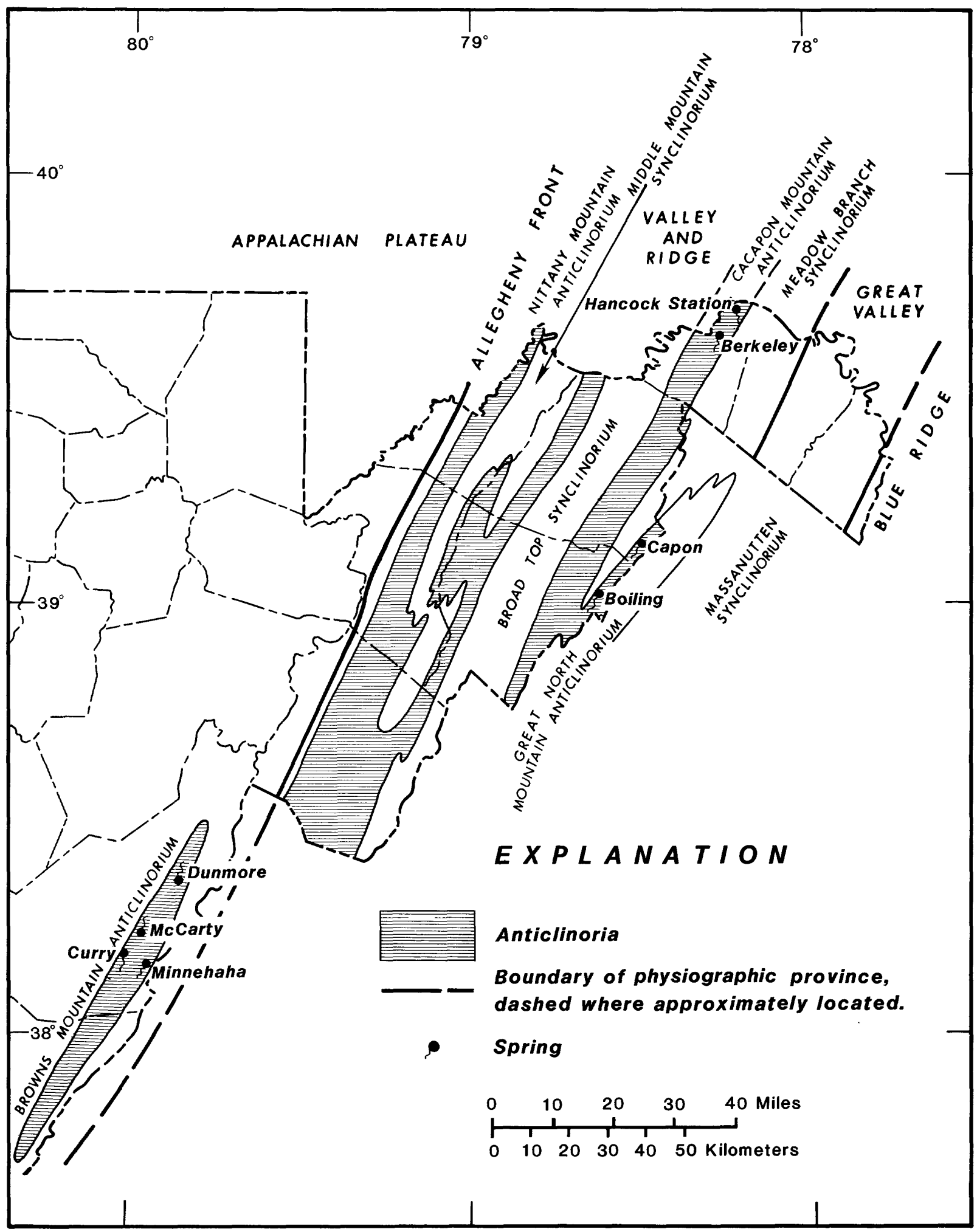

Base from West Virginia Geological and

Economic Survey Map-14, 1:1,000,000

Figure 2. Map showing physiographic provinces, warm springs, anticlinoria, and synclinoria of eastern West Virginia. 
in delineating the geology adjacent to the area of the warm springs. A Landsat linear features map of West Virginia (Reynolds, 1979) was compared with the linear features mapped from SLAR images.

Several hydrologic reports pertain to springs in eastern West Virginia: Price and others (1936) and Erskine (1948) contain flow and temperature data for some of the warm springs; Rogers (1843, p. 331 and 340) noted that springs "...issue from the lines of anticlinal axes, or from points very near such lines," and "...issue from the steep-dipping on [sic] inverted strata on the northwest side of the anticlinals...". Later reports by Hobba and others (1972) and Hobba (1984), and Clark and others (1976), describe the water resources of the Potomac River and New River basins, respectively. These reports contain flow and water-quality data for some of the warm springs.

The only recent investigation dealing with warm springs in the study area was by Hobba and others (1979). This was an investigation of 10 of the largest and warmest thermal springs in the Appalachians from Georgia to New York. The study included two springs in West Virginia (Minnehaha Springs and Berkeley Springs), and used modern geochemical techniques and remote sensing to identify common regional characteristics of the geothermal systems. The SLAR images then available, were useful in delineating lineaments and some previously mapped faults in the vicinity of thermal springs in Georgia, Virginia, and in the Minnehaha Springs area of West Virginia.

Moore and Sheehan (1981) reported the results of other investigators in an evaluation of SLAR images for geologic and cartographic applications. They concluded that the images were more useful as a supplementary rather than a primary tool in hydrologic investigations in Alaska, Montana, and Utah. Pascucci and others (1981) evaluated the applicability of SLAR images for mapping structural geologic features (probable faults, lineaments, and axes of synclines and anticlines) in Alaska. They found that radar images contributed additional linear features not detectable on Landsat images or aerial photographs, but they also noted that some linear features, previously mapped on Landsat images and aerial photographs, were obscure on radar images.

\section{Acknowledgments}

The authors wish to thank Douglas Patchen, and Lee Avary of the West Virginia Geological and Economic Survey and Joseph Chemerys of the U.S. Geological Survey for their assistance during this study. We also thank the numerous land owners for allowing us access to their land, springs, and wells. 


\section{DESCRIPTION OF SIDE-LOOKING AIRBORNE RADAR}

Side-looking airborne radar imagery is acquired from an airplane or satellite by transmitting microwave energy at an acute angle measured from the horizontal toward the earth's surface. Some of the energy reaching the earth is reflected back to an antenna on the side of the vehicle. The intensity of the reflection is determined by the roughness of vegetation or the terrain, the angle of the terrain with respect to the radar antenna, and the dielectric constant of the target. The reflections received by the antenna are recorded photographically or digitally.

As shown in figure 3, SLAR imagery generally is recorded simultaneously from reflections between two angles. A "near view" (steep depression angle, about $21^{\circ}$ to $31.4^{\circ}$ below horizontal) is generally better for investigating areas of high relief, whereas a "far view" (shallow depression angle, $10.9^{\circ}$ to about 21 below horizontal) is generally better for investigating areas of low relief.

According to Moore and Sheehan (1981, p. 4), there are two types of SLAR systems: (1) realaperture radar systems that record images directly on film aboard the vehicle, and (2) synthetic-aperture radar systems that record the radar equivalent of a hologram in which the final film image is produced by later optical or digital processing.

The resolution of real-aperture radar systems decreases with distance from the vehicle because the radar-beam width increases with distance. Synthetic-aperture radar systems achieve a nominal resolution of 10 to 66 feet regardless of distance from the vehicle, and show more surface detail on enlarged images.

The SLAR images used for this study are mosaics of near-view synthetic-aperture radar strips at a scale of 1:250,000 to match the Cumberland and Charlottesville quadrangle maps (fig. 1). The original SLAR film strips at a scale of 1:400,000 were also examined, but not extensively used. The imagery was acquired in September 1982 from an altitude of 7.5 miles with a west look. The depression angle was approximately $20^{\circ}$ and yielded a ground- swath width of 23 miles with a resolution of 33 feet. The radar system used was "X-band," having a wavelength of 1.22 inches, a frequency of 9.6 Gigahertz, and $\mathrm{H}-\mathrm{H}$ (horizontal-horizontal) polarization. Additional information on radar systems is given in Moore and Sheehan (1981).

\section{Detection of Lineaments by Side-Looking Airborne-Radar and Landsat Imagery}

Lineaments are well defined on the SLAR images used in this study. The resolution of 33 feet for the SLAR images exceeds that of the Landsat multispectral-scanner images. Most of the mapped lineaments are valleys that range in size from gullies 1 mile long to linear depressions several tens of miles in length. Figures 4, 5, and 6 are SLAR-image enlargements that show the warm-spring areas and the mapped lineaments.

Lineaments detected by SLAR imagery predominantly trend northeast and northwest (fig. 7). Northwest trending lineaments cut at about 90 degrees to the strike of the regional structure, whereas the northeast trending lineaments cut 30 to 40 degrees to the regional strike. Lineaments appear less pronounced in the gently dipping rocks of the Appalachian Plateau. However, warm springs are not known in most of the Plateau and thus a detailed analysis was not made of SLAR images in this area.

A comparison of lineaments (Reynolds, 1979) detected by Landsat images and lineaments detected by SLAR images was made. The lineaments detected on Landsat images exhibit the same northwest and northeast trends found on SLAR images. Although some linear features match, the overall lineament correlation is poor because there are about five times more lineaments detected on SLAR images than on Landsat images. A brief analysis of the SLAR and Landsat images indicate that SLAR images clearly show more lineaments and have higher 


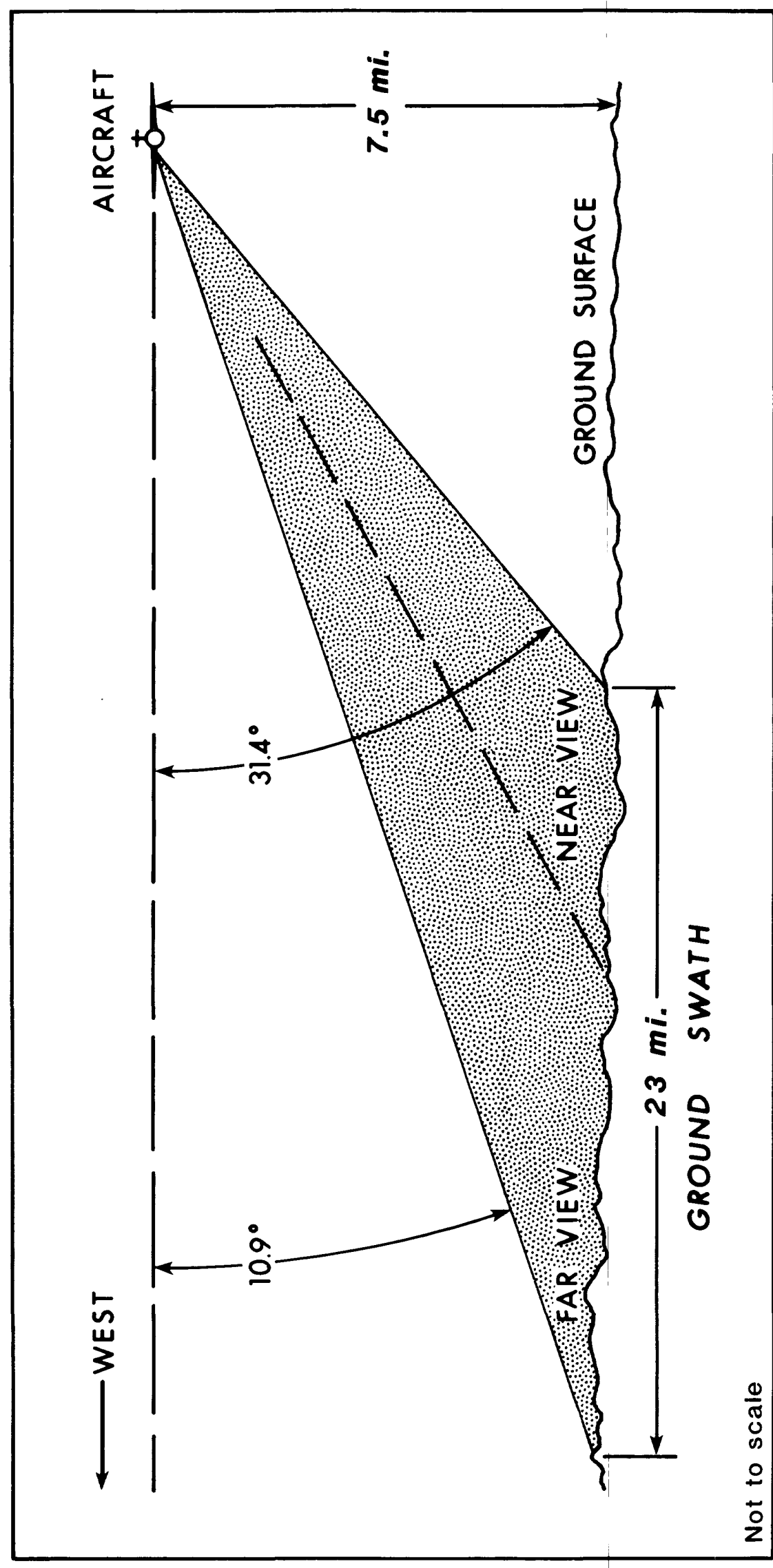

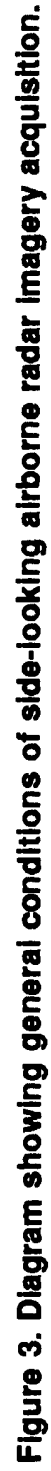




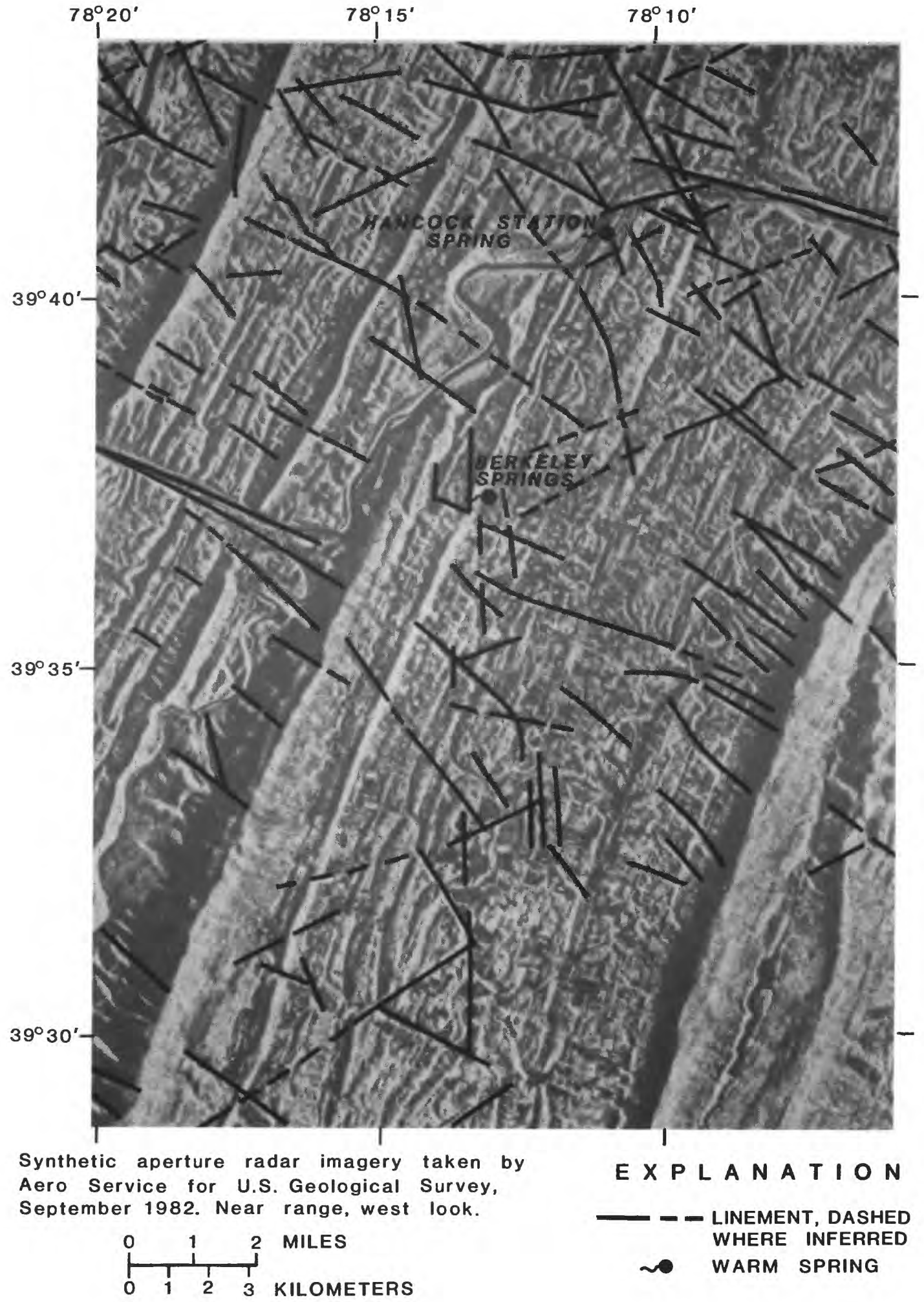

Figure 4. Side-looking airborne-radar image showing lineaments in Berkeley Springs and Hancock Station spring area. 


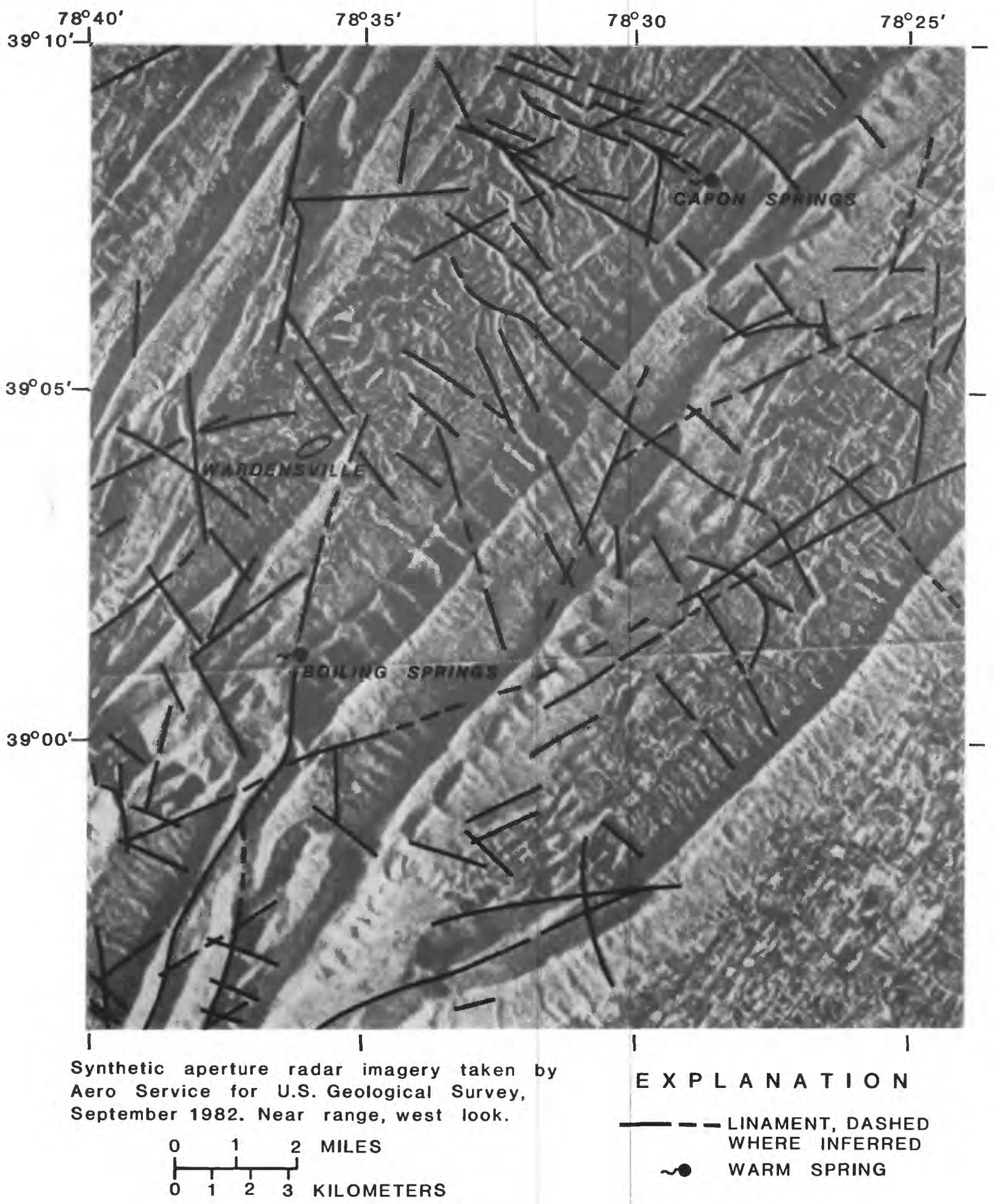

Flgure 5. SIde-looking airborne-radar image showing lineaments in Capon Springs and Boiling Springs area. 


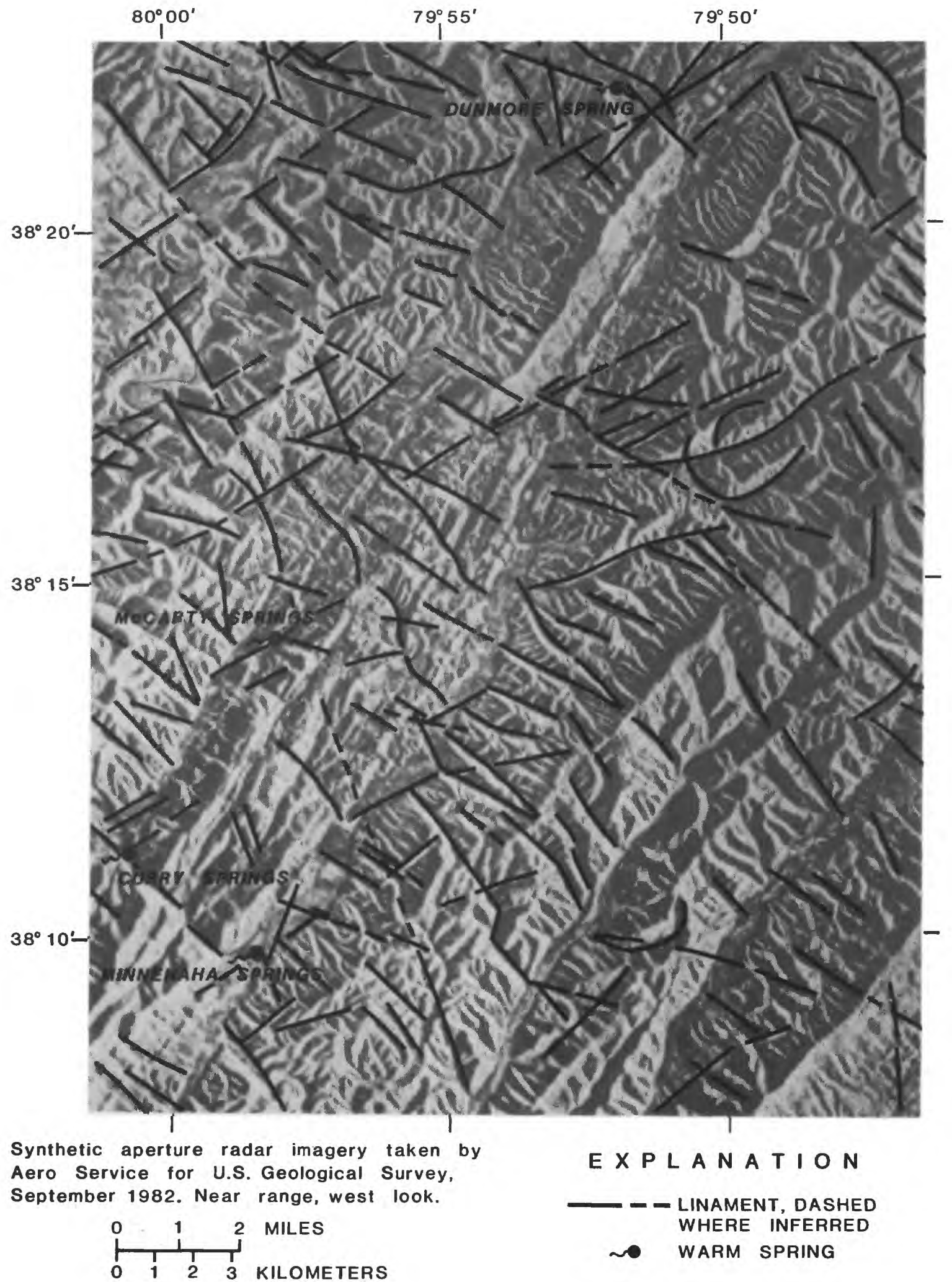

Flgure 6. Side-looking airborne-radar Image showing lineaments in Minnehaha, Curry, McCarty, and Dunmore Springs area. 

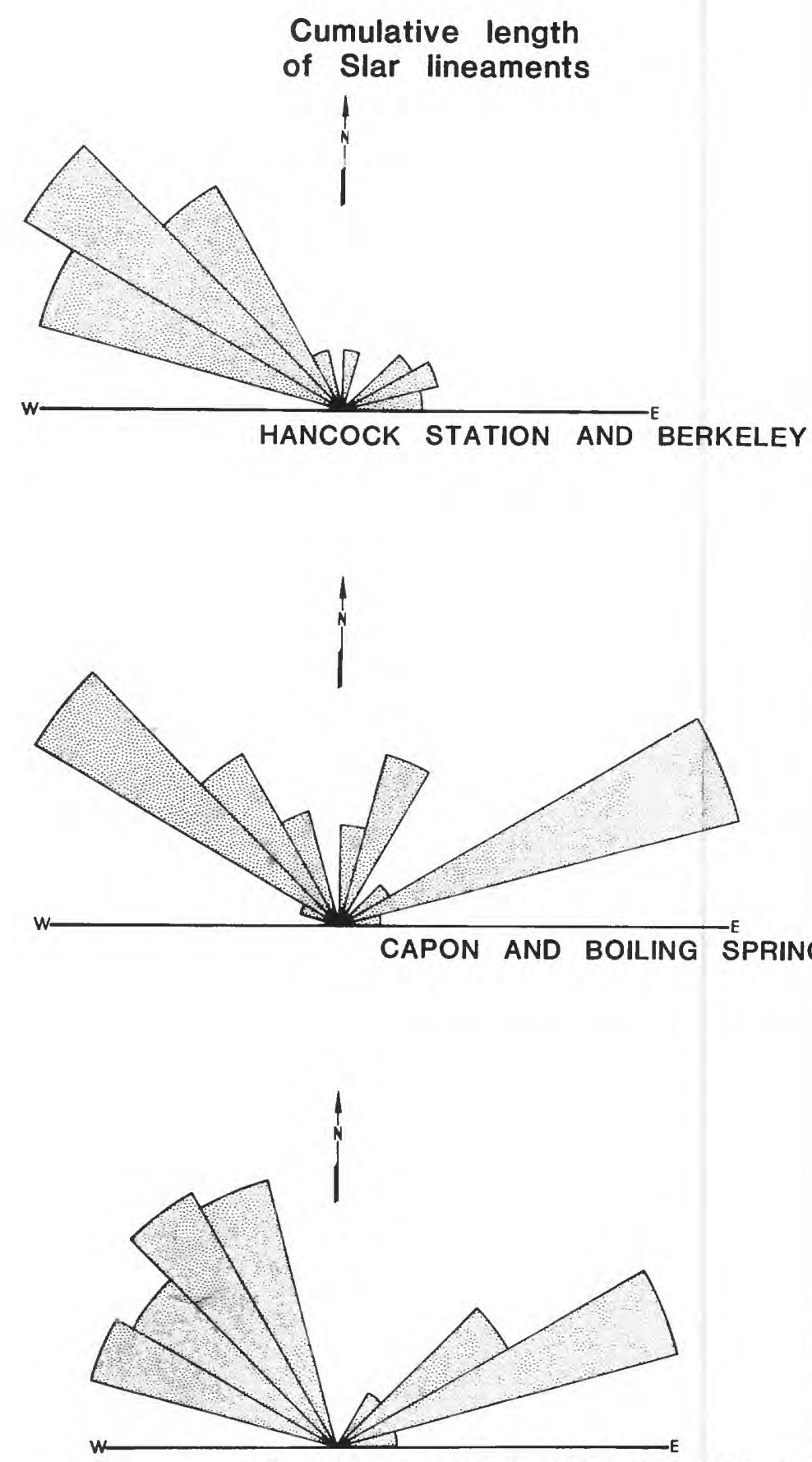

MINNEHAHA, CURRY, MCCARTY, AND
Cumulative Frequency of fracture trends

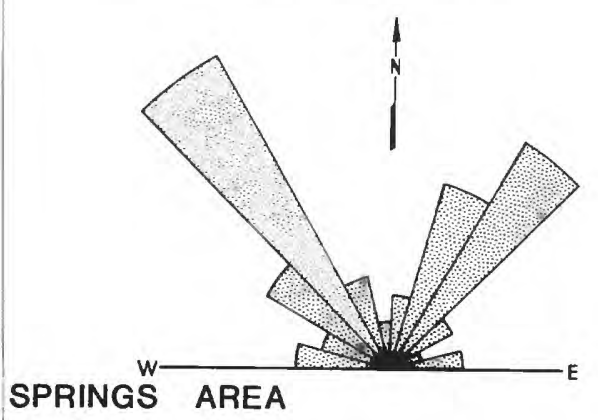

AREA

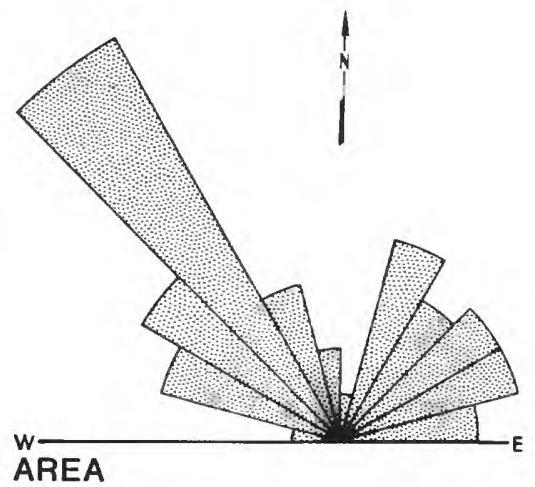

Figure 7. Rose dlagrams of cumulative length of lineaments mapped on side- looking airborne-radar Images and cumulative frequency of fracture trends measured in the rocks at selected warm-spring areas. 
resolution. However, large lineaments are more readily mapped from the small-scale $(1: 1,000,000)$ Landsat images.

Although SLAR is a good tool for detecting lineaments, the resulting images are biased by look direction and depression angle. That is, lineaments that parallel the look direction may not be visible on the image, whereas those that form an oblique angle with the look direction will be apparent because of the shadow they form. If the look angle is too small, hills or ridges may cast large shadows and obscure lineaments within the shadow. Directional bias may be reduced by obtaining images of more than one look direction or by stereoscopically viewing radar-image pairs.

\section{Side-Looking Airborne-Radar Imagery and Geology}

Side-looking airborne radar images superimposed over the West Virginia State Geologic map (Cardwell and others, 1968) indicate that topographic relief correlates well with geologic formations and structure, particularly in the Valley and Ridge physiographic province. The mountains, which are underlain by folded and thrust-faulted formations, containing a high percentage of sandstone. Valleys are predominantly underlain by shales, siltstones, and carbonates with minor sandstone. The less resistant shale, siltstone, and carbonate units in the valleys have a higher drainage density than the more resistant sandstones in the ridges. Thus, lithology and large-scale structure can be inferred from SLAR images based on topographic relief and differences in drainage density.

Although warm springs cannot be detected on SLAR images, the images can be used to delineate subtle lithologic differences, lineaments, folds, and stratigraphic offsets associated with warm-spring areas. The warm-spring areas can be further examined using high-altitude color-infrared and low- altitude black-and-white photographs. Lineaments detected by use of SLAR imagery cannot be considered synonymous with faults and fractures until verified in the field. Likewise, lithological, structural, and formational correlations must be based on field examinations. 


\section{RELATION BETWEEN WARM SPRINGS AND GEOLOGY}

The eight warm springs have several common characteristics (table 1). All the springs are in topographic lows on or near steeply dipping beds of Oriskany Sandstone. The Oriskany Sandstone commonly occurs in complex geologic structures that have been folded and faulted. As a result, the Oriskany Sandstone can be conducive to deep ground-water circulation and the development of warm springs. Those springs not discharging from Oriskany Sandstone discharge from adjacent limestones of the Helderberg Group. However, circulation to the two springs in the Helderberg Group may be mainly through the Oriskany Sandstone. Although three springs are on the noses of plunging folds of Oriskany Sandstone, they are not directly on steeply inclined beds. In all cases, adjacent less-permeable shales act as a barrier that channels water through the fractured sandstone or carbonate rocks.

\section{Berkeley Springs and Hancock Station Spring Area}

Berkeley Springs, Berkeley County, and Hancock Station Spring, Morgan County, are on the east limb of Cacapon Mountain Anticlinorium (figs. 8 and 9). Both discharge from the Oriskany Sandstone near its contact with the overlying Marcellus Shale.

The geological map by Minke (1964) was used to describe the geology for this area (figs. 8 and 9). Both Berkeley Springs and Hancock Station Spring discharge from the Oriskany Sandstone at the eastern edge of the Cacapon Mountain Anticlinorium where the rocks dip steeply to the east into the Timber Ridge Syncline (fig. 10).

Lineaments detected by use of SLAR imagery for the Berkeley Springs area have been delineated on 1:125,000 scale images (fig. 4). Rose diagrams (fig. 7) show cumulative length of lineaments mapped from SLAR images and cumulative frequency of measured fracture trends. The distinct N. $15-45^{\circ} \mathrm{E}$. fracture trend on the rose diagram for the Berkeley Springs area (fig. 7) does not appear on the corresponding length of lineament rose diagram. Although the northwest quadrant rose diagrams compare favorably, the lineaments-trend maximum is oriented farther west than the fracture-trend maximum.

Ground-water flow in the Berkeley Springs area near the Cacapon Mountain Anticlinorium is generally to the northeast. Recharge for Berkeley Springs probably is derived from precipitation on the Oriskany Sandstone outcrop south and north of the spring (fig. 9). Low water levels in wells in the Oriskany Sandstone as far as 11 miles south of the spring suggest that as much as two-thirds of the total spring discharge is derived from precipitation on the Oriskany Sandstone outcrop 11 miles south of the spring.

Water from the recharge area apparently percolates downward along open bedding planes and fractures in the friable Oriskany Sandstone to a postulated back-thrust fault, which has broken or truncated the sandstone (fig. 10). At this point, the water moves along the fault, perhaps through other deep, permeable zones toward the spring. A nearly vertical permeable zone may be present near the spring as indicated by a straight SLAR lineament that trends N. $60^{\circ} \mathrm{W}$. through the area (fig. 4). (Trainer and Ellison (1967) report that straight lineaments indicate vertical or near vertical fractures). The permeability along this lineament is probably high enough to permit a large volume of water to rise quickly from depth to the spring without appreciable heat loss.

The low tritium content (2.6 Tritium units) ${ }^{1 /}$ in the spring water suggests that most of the water discharging from the spring is older than 30 years. If the tritium content in the thermal component of the spring water is assumed to be zero, and if the tritium content of both the recharge water (35 TU), and the spring-discharge water $(2.6 \mathrm{TU})$ can be measured (table 1$)$,

${ }^{1 /}$ A Tritium unit (TU) is defined as a radioactive decay rate of 3.2 picocuries per liter of water. 


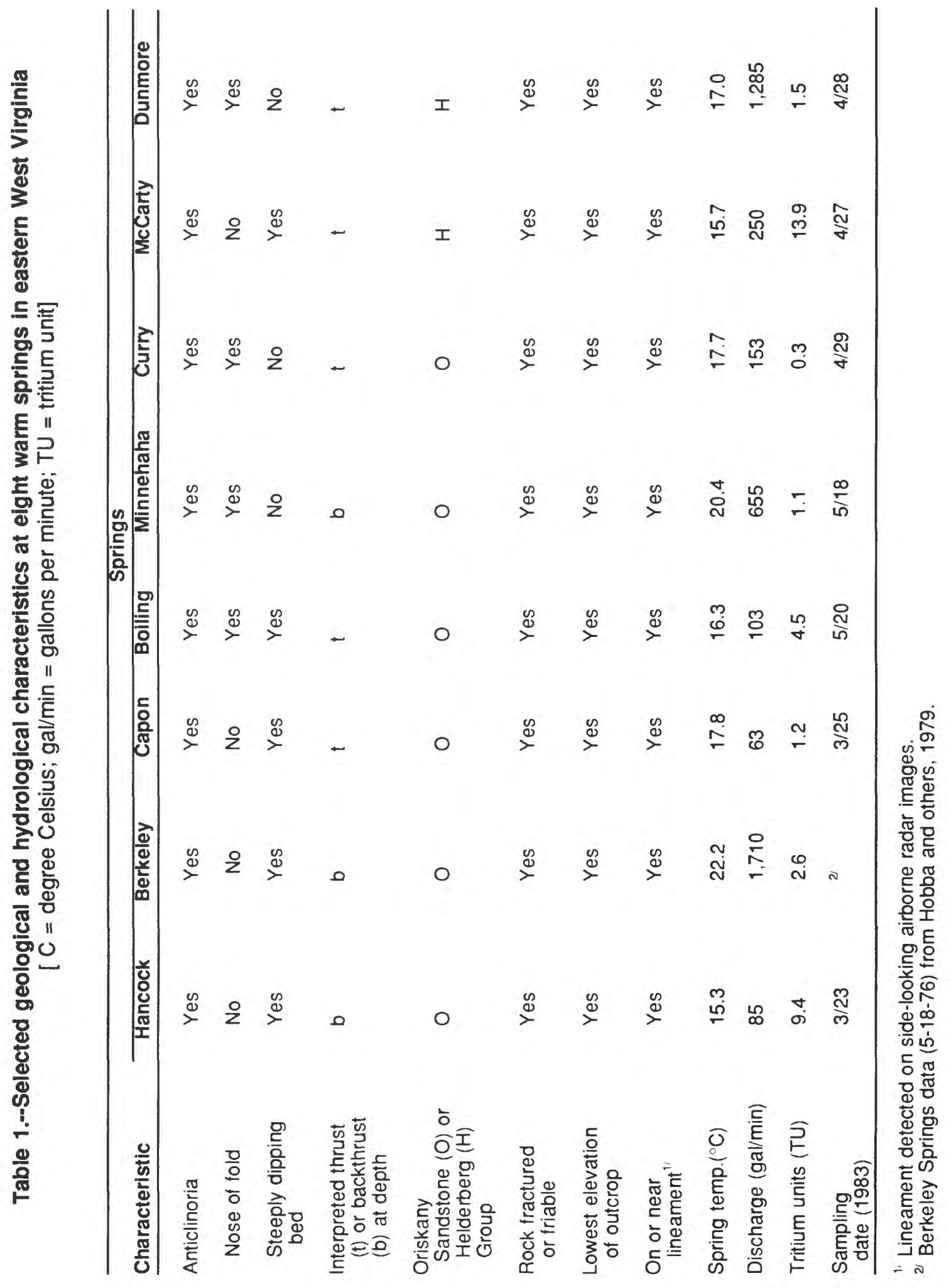




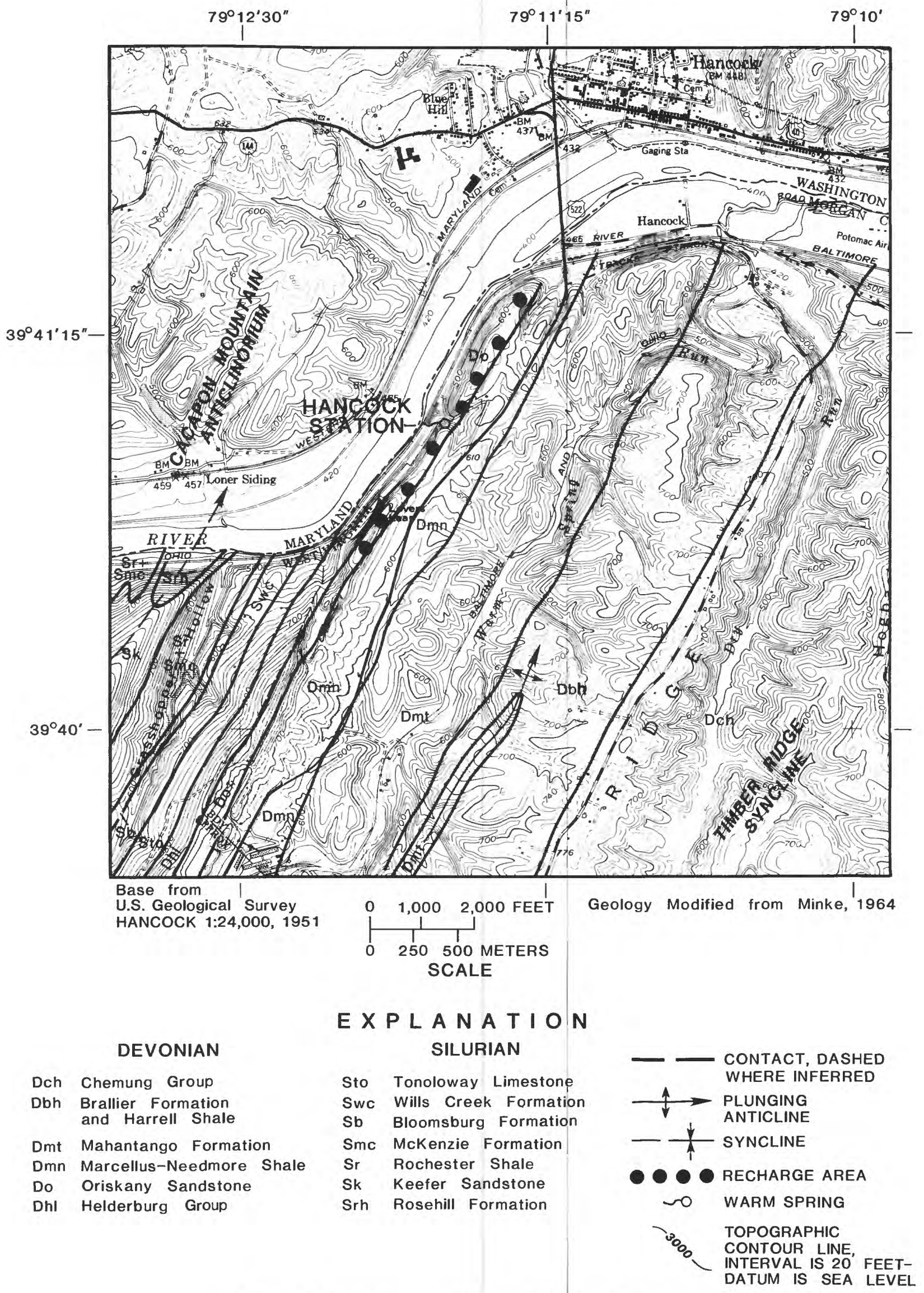

Figure 8. Geologic map of Hancock Station Spring area. 


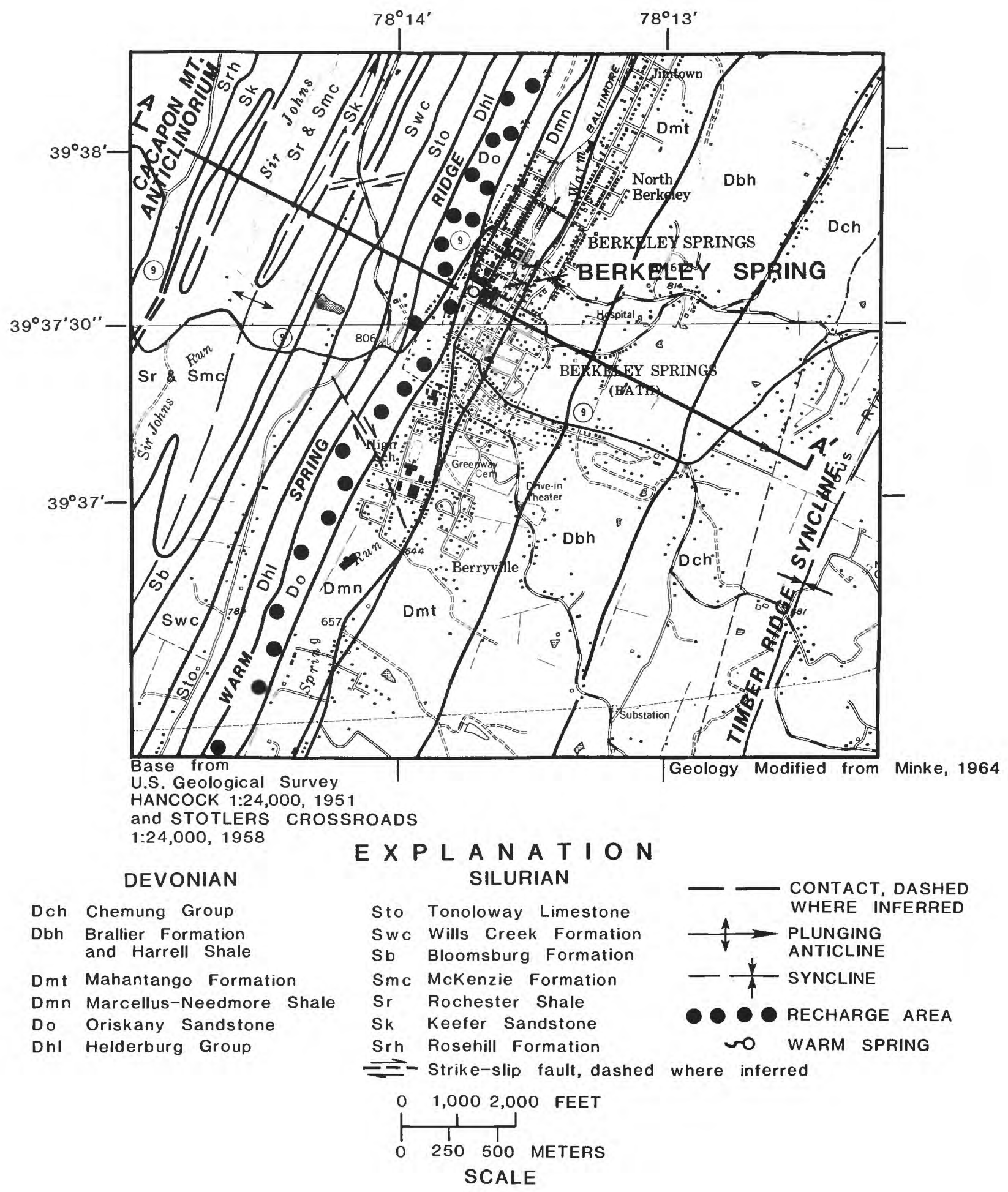

Figure 9. Geologic map of Berkeley Springs area (Cross section A-A' shown in figure 10). 


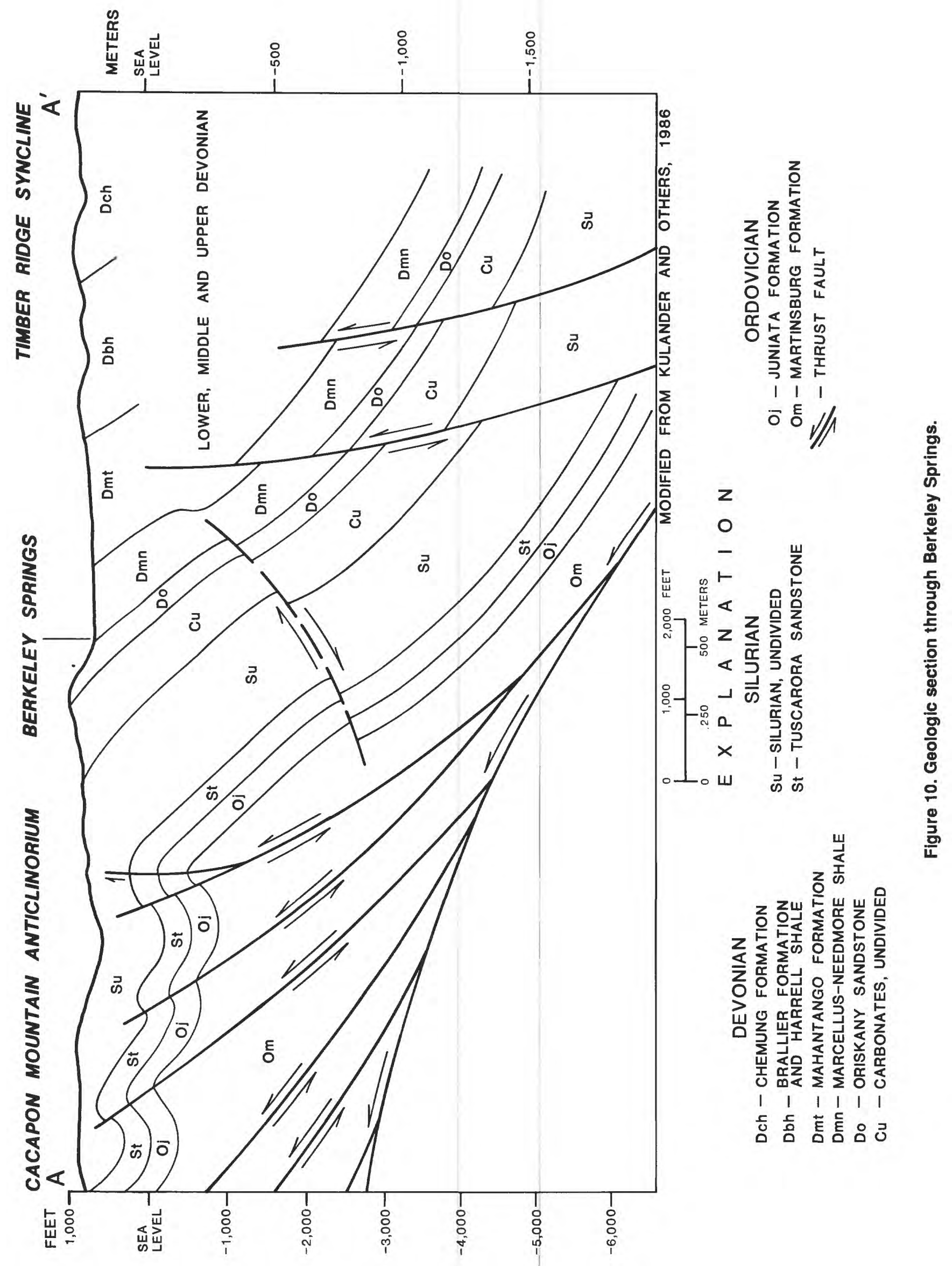


then the proportions of thermal and recharge water can be estimated by the equation (Hobba and others, 1979, p. 26): A Tritium unit (TU) is defined as a radioactive decay rate of 3.2 picocuries per liter of water.

$$
C_{s w}=C_{t w} t w+C_{c w}(1-t w)
$$

where,

$\mathrm{C}_{\mathrm{Bw}}=$ tritium content of discharging spring water $=2.6 \mathrm{TU}$

$\mathrm{C}_{\mathrm{tw}}=$ tritium content of thermal portion of spring water $=0 \mathrm{TU}$

$\mathrm{C}_{\mathrm{cw}}=$ tritium content of recharge water $=35 \mathrm{TU}$

$\mathrm{tw}=$ proportion of thermal water, and

$(1-\mathrm{tw})=$ proportion of recharge water.

Therefore:

$$
\begin{aligned}
2.6 \mathrm{TU} & =(0 \mathrm{TU})(\mathrm{tw})+35 \mathrm{TU}(1-\mathrm{tw}) \\
\mathrm{tw} & =\frac{(35-2.6)}{35} \\
\mathrm{tw} & =0.93
\end{aligned}
$$

Using the equation:

$$
T_{\mathrm{cw}} \mathrm{Q}_{\mathrm{cw}}+\mathrm{T}_{\mathrm{tw}} \mathrm{Q}_{\mathrm{tw}}=\mathrm{T}_{\mathrm{sw}} \mathrm{Q}_{\mathrm{sw}}
$$

where,

$\mathrm{T}_{\mathrm{c} \mathrm{w}}=$ average background temperature of shallow ground water in Berkeley Springs area $=12.5^{\circ} \mathrm{C}$,

$\mathrm{T}_{\mathrm{tW}}=$ temperature of deep, warm ground water,

$\mathrm{T}_{\mathrm{sw}}=$ temperature of spring discharge $=22.2^{\circ} \mathrm{C}$,

$Q_{\mathrm{sw}}=$ total flow of spring $=1,710 \mathrm{gal} / \mathrm{min}$,

$Q_{\mathrm{cw}}=$ flow of shallow ground-water component $=Q_{\mathrm{sw}(1-\mathrm{tw})}=120 \mathrm{gal} / \mathrm{min}$,

$Q_{\mathrm{tw}}=$ flow of water component older than $30 \mathrm{yrs}=Q_{\mathrm{sw}(\mathrm{tw})}=1,590 \mathrm{gal} / \mathrm{min}$,

the temperature of the warm water $\left(\mathrm{T}_{\mathrm{tw}}\right)$ at Berkeley Springs can be calculated.

Therefore:

$$
\begin{aligned}
& (12.5)(120)+\left(\mathrm{T}_{\mathrm{tw}}\right)(1,590)=(22.2)(1,710) \\
& \mathrm{T}_{\mathrm{tw}}=\frac{37.96-1,500}{1,590} \\
& \mathrm{~T}_{\mathrm{tw}}=22.9^{\circ} \mathrm{C}
\end{aligned}
$$

Thus, $\mathrm{T}_{\text {tw }}$ is about $23.0^{\circ} \mathrm{C}$. This is $10.5^{\circ} \mathrm{C}$ warmer than the average background temperature $\left(12.5^{\circ} \mathrm{C}\right)$ of shallow, cool ground water. The average geothermal gradient in the region (determined from temperature logs from six oil and gas wells in adjacent counties) is 
about $1.9^{\circ} \mathrm{C}$ per 330 feet of depth. Thus, assuming no loss of heat by conduction, the minimum depth of circulation at the spring is about 1,825 feet.

$$
\frac{10.5^{\circ} \mathrm{C}}{1.9^{\circ} \mathrm{C}}=5.53 \times 330 \text { feet }=1,825 \text { feet }
$$

The circulation of water to Hancock Station Spring is probably similar to that at Berkeley Springs. Much of the water probably moves from the south to the northeast through the Oriskany Sandstone. Back-thrust faults beneath the Cacapon Mountain Anticlinorium may limit the depth of ground- water circulation (fig. 10). Lineaments near the spring (fig. 4) suggest vertical fractures. Upward migration of warm water from depth may be facilitated by increased permeability along these fractured zones. A tritium content of $9.4 \mathrm{TU}$ in the spring water and a range of 32 to $70 \mathrm{TU}$ in recharge water indicates that 70 to 85 percent of the water is more than 30 years old. Minimum depth of circulation to the spring is 740 feet based on calculations using spring flow and temperature, geothermal gradient, and the average background temperature of shallow recharge water.

\section{Capon Springs and Boiling Springs Areas}

This area includes Boiling Springs in Hardy County and Capon Springs in Hampshire County (fig. 1). Boiling Springs, in a relatively remote wooded area, is 3.5 miles south of Wardensville (fig. 5). Capon Springs, which is enclosed by a small stone structure at a recreation area (fig. 11), is 8 miles northeast of Wardensville (fig. 5). Both springs are located on the northwest limb of the Great North Mountain Anticlinorium (fig. 2), and both discharge from the Oriskany Sandstone (figs. 12 and 14).

Previous geologic mapping in the area was done by Tilton and others (1927). However, the SLAR images and aerial photographs revealed complex geology that required detailed remapping in the vicinity of these two springs (Dean and others, 1985). The remapped geology (figs. 12-15) illustrates the complex folding and faulting. Boiling Springs is on the east flank near the hinge of a small, overturned anticline in Oriskany Sandstone that plunges steeply to the east-northeast (fig. 13). Northwest of Boiling Springs is the complexly folded Anderson Ridge Anticline, and to the southeast lies the intensely folded Great North Mountain Anticlinorium (fig. 13). These two structures are separated by thrust faults that dip to the southeast and a north-northeast trending lineament zone delineated by the plunge-out of short wavelength en echelon folds in the Oriskany Sandstone. The thrust faults and en echelon foldtrend, where they were interpreted from SLAR imagery, form a pronounced lineament along Waites Run (fig. 12). This lineament contributes significantly to the N. 15-30 E. lineament trend for the Capon Springs area shown in figure 5.

Lineaments detected on SLAR images and fracture trend maximums in the Capon Springs area (fig. 5) generally correlate in the north westward and northeastward directions. However, the fracture maxima in the northeast quadrant have a much broader range than does the lineament maxima.

The recharge for Boiling Springs may be derived from precipitation entering the Oriskany Sandstone outcrop south and southwest of the spring (fig. 12). Some of the water entering the outcrop percolates down gradient, which coincides with downdip and down-plunge, along open bedding planes and fractures to where the Oriskany Sandstone is probably truncated by an east-dipping thrust fault (fig. 13). The water then may move along the fault zone, and migrate updip and up-plunge along the fracture hinge of the anticline where the Oriskany Sandstone is overlain by the relatively impermeable Marcellus Shale. The ascending warm water emerges on the approximate hinge of the anticline at the lowest point of the Oriskany Sandstone 


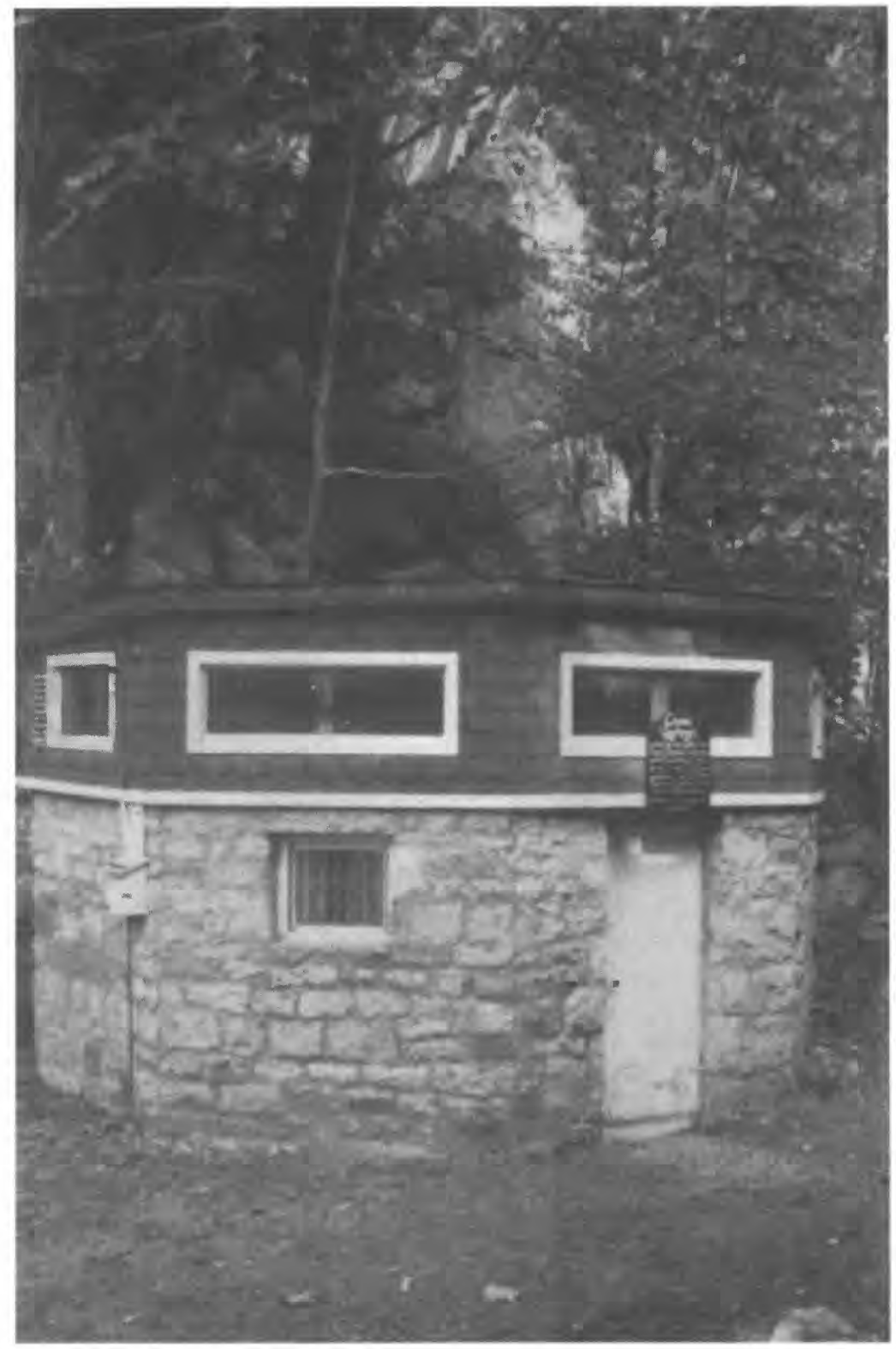

Figure 11. Capon Springs and near-vertical Oriskany Sandstone beds in background. 


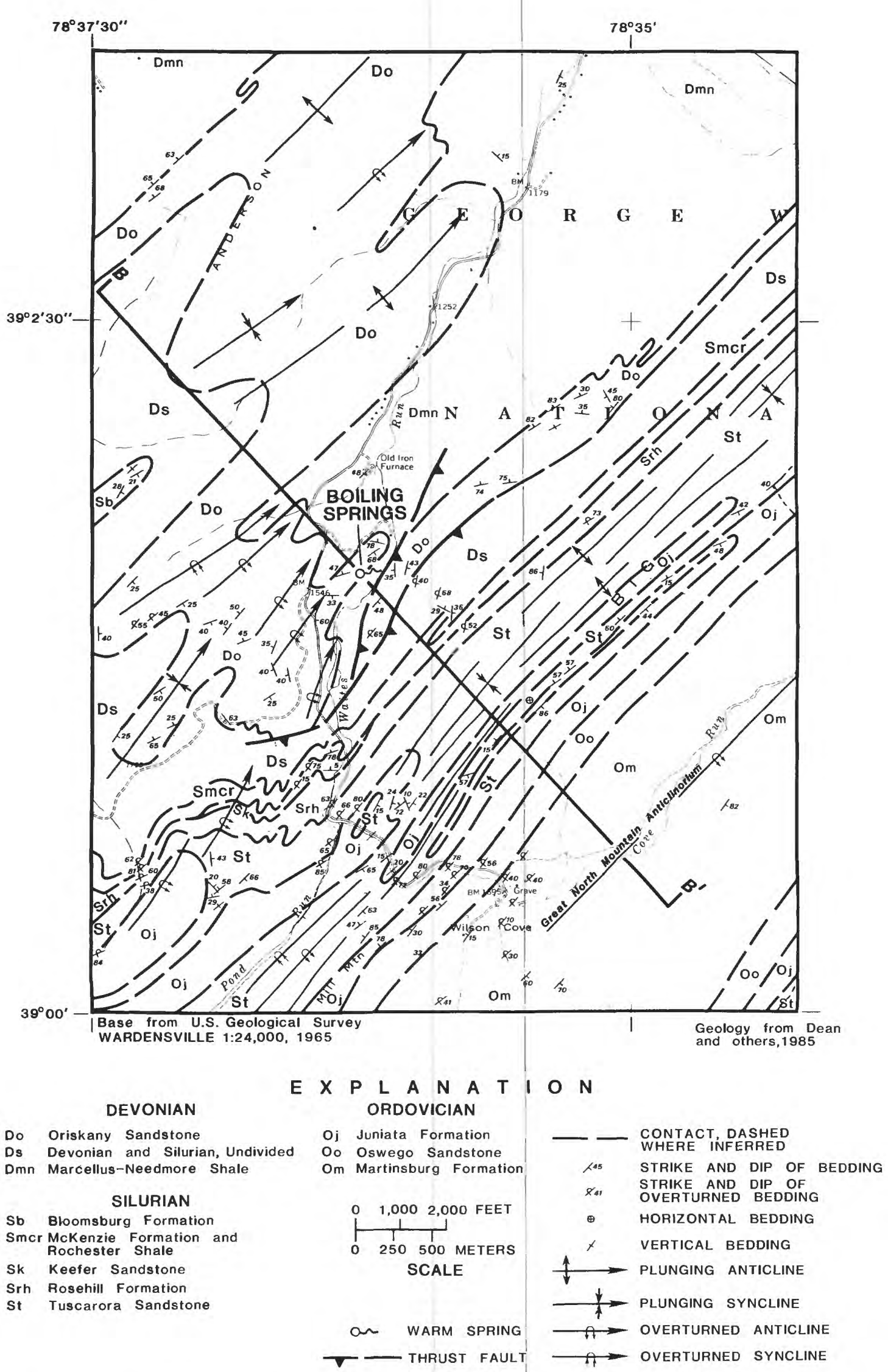

Figure 12. Geologic map of Boiling Springs area (Cross section B-B' shown in figure 13). 


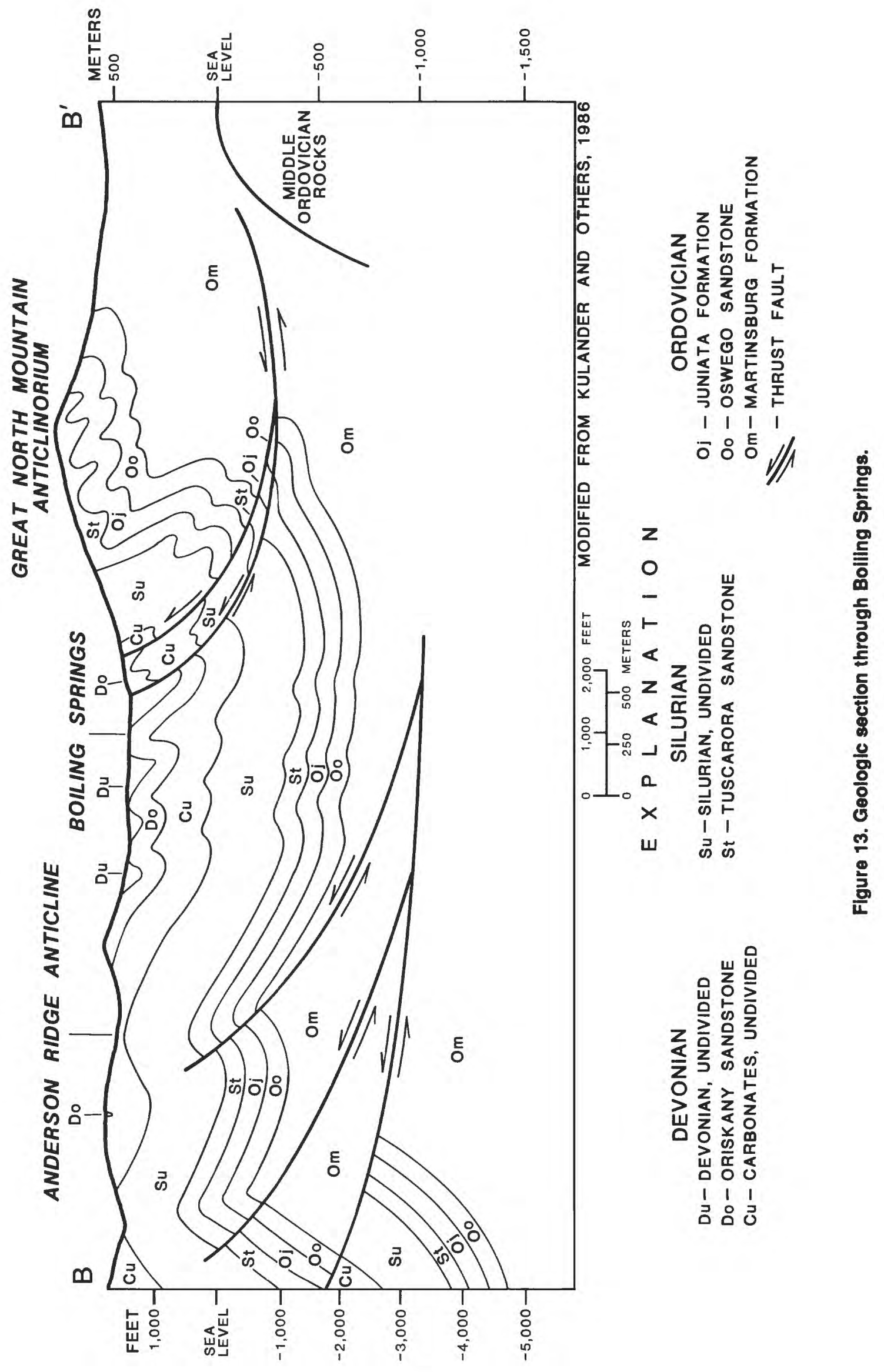




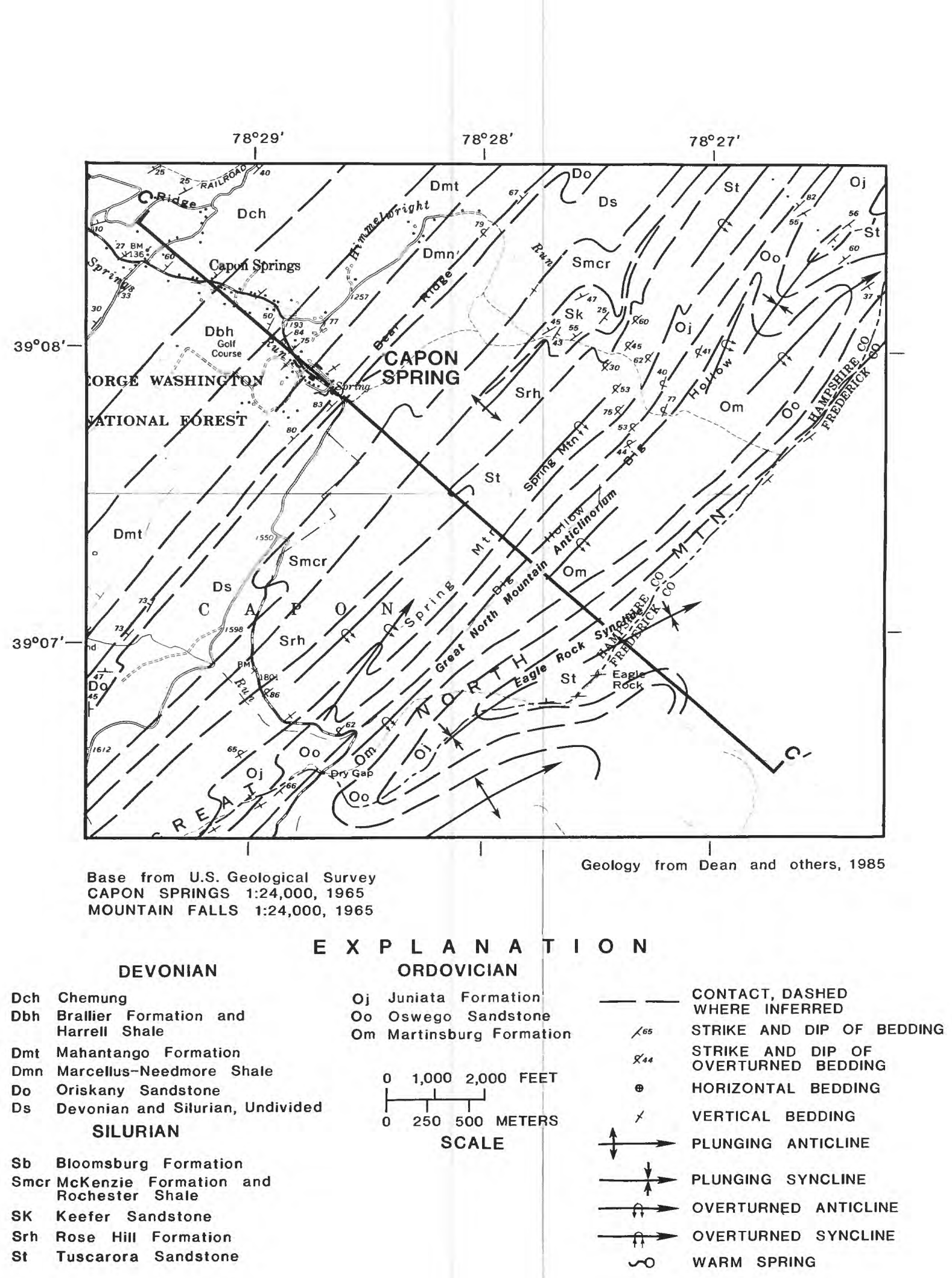

Figure 14. Geologic map of Capon Springs area (Cross sectlon C-C' shown In figure 15). 


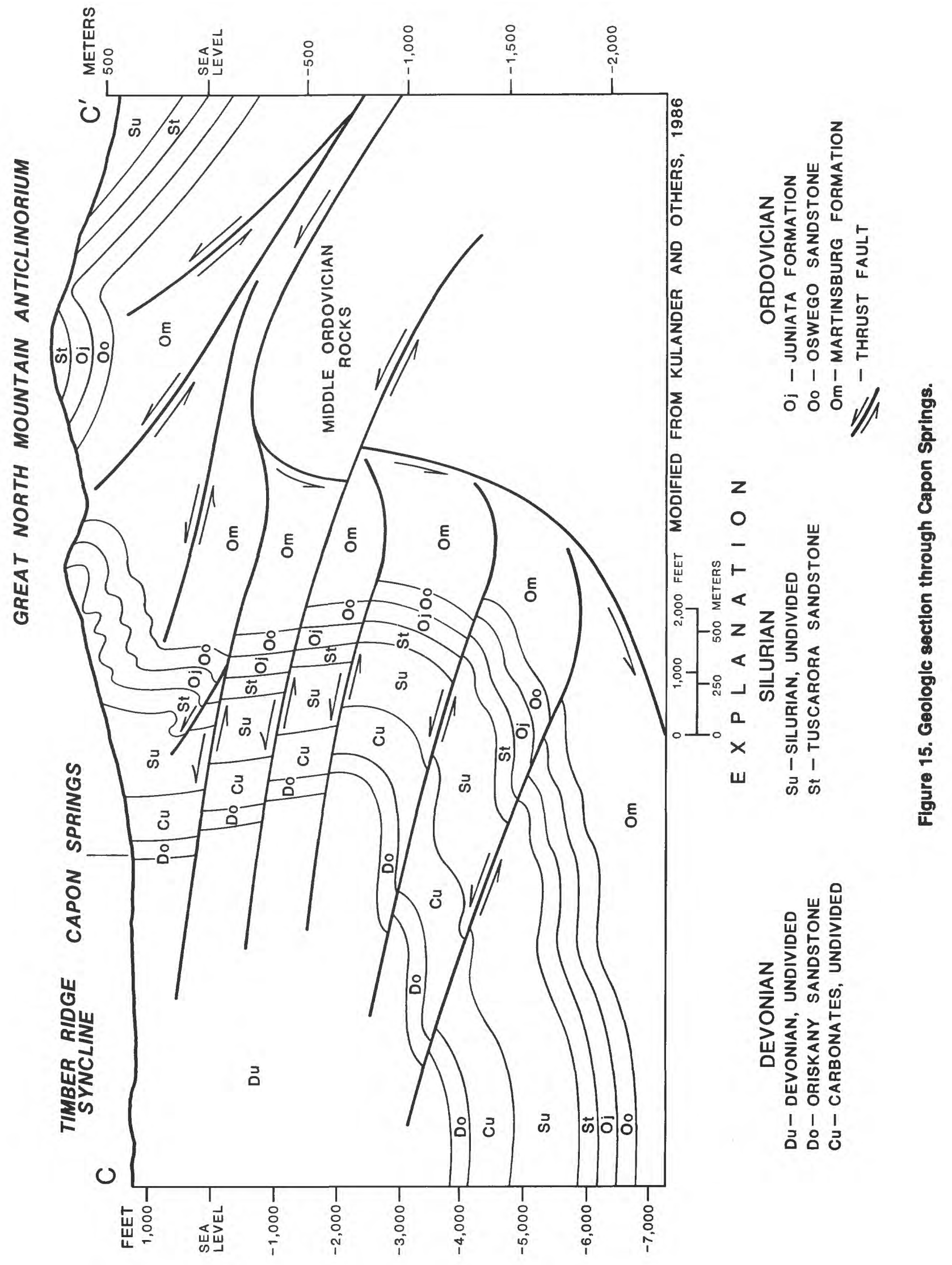


outcrop. Once the fractured hinge line is filled with warm water, the decreased density and viscosity of the warm water aid in driving water through the spring system.

Another recharge area for the spring may be the Oriskany Sandstone outcrop immediately east of Boiling Springs (fig. 12). Water from this area could move downward and southwestward along open bedding planes and joints in the Oriskany (and perhaps in Devonian-Silurian carbonates), as well as along the thrust fault, to a depth of at least 820 feet, where it intersects the Oriskany Sandstone. Here, the water would enter the Oriskany Sandstone and migrate updip along open bedding planes to emerge at Boiling Springs. Supporting evidence for thrust-fault control on deep ground-water circulation is an alignment of small springs along the fault trace just east of Boiling Springs. These springs show slightly elevated temperatures, suggesting deep circulation. However, their flow is so small and widespread that the heating may be caused by solar heating.

It is possible that both recharge areas, previously mentioned, contribute water to Boiling Springs. The tritium content (4.5 TU) in Boiling Springs and in the recharge water (31-65 TU) suggests that 85 to 95 percent of the water is more than 30 years old. Minimum depth of circulation of water supplying the spring is estimated to be $820 \mathrm{feet}$, based on calculations using the flow rate and temperature of the spring (table 1), geothermal gradient, and the temperature of shallow recharge water.

Capon Springs (fig. 14) is 11 miles northeast of Boiling Springs (fig. 2) in a gap eroded through steeply dipping Oriskany Sandstone (figs. 14 and 15). Surface geology is structurally simple. Northwest of the spring is Timber Ridge Syncline (fig. 15). It is a broad open fold plunging 5 to $10^{\circ} \mathrm{NE}$. From the axis of this syncline eastward, the dip of the rocks progressively steepens until it is nearly vertical at Capon Springs (figs. 14 and 15). Further east, the Great North Mountain Anticlinorium displays complex, overturned folds similar to the Boiling Springs area.

Recharge for Capon Springs is probably derived from precipitation on the elevated and highly fractured Oriskany Sandstone outcrop north and south of the spring. The water percolates downward along open bedding planes and fractures in the steeply dipping beds. Here, truncation of the Oriskany by an interpreted thrust fault (fig. 16) probably limits further downward migration of water and promotes lateral water movement along the fault. The warm water may flow laterally until it ascends along a vertical fracture zone and emerges at Capon Springs. The spring is located at the lowest elevation along a 17-mile stretch of Oriskany Sandstone outcrop belt. Figure 16 is a schematic diagram of a cross section along the strike of the Oriskany Sandstone through the Springs.

Capon Spring discharges about $63.4 \mathrm{gal} / \mathrm{min}$ year-round, therefore, about $63.4 \mathrm{gal} / \mathrm{min}$ of recharge must enter the Oriskany Sandstone recharge area from precipitation and streams. Perhaps half of this recharge enters the outcrop area northeast of the spring and half enters the outcrop area southwest of the spring. Assuming recharge from precipitation is about 7.9 inches annually, then a recharge area of 148 acres is necessary to maintain a flow of 63.4 $\mathrm{gal} / \mathrm{min}$ at the spring. The Oriskany Sandstone outcrop area is about 200 feet wide; therefore, the recharge area is estimated to be about 3 miles long on each side of the spring. If recharge from precipitation is less than 7.9 inches, then a larger recharge area (length of outcrop) would be required. If some recharge is derived from small streams crossing the Oriskany or if more recharge is derived from precipitation or adjacent rocks, then a smaller recharge area would be required.

Water movement down to the presumed fault at about 1,000 feet (fig. 16) is primarily along open vertical fractures and bedding planes with possible additional movement along horizontal fractures. The fracture systems illustrated in figure 16 have been observed in the field.

Tritium content (1.2 TU) in the spring water and in the recharge water (31-65 TU) suggests that 96 to 98 percent of the water is older than 30 years. Minimum depth of circulation of water supplying the spring is estimated to be at least 1,015 feet. Assuming most of the water enters the aquifer at points 1.5 miles north and south of the spring (midpoints of the assumed 


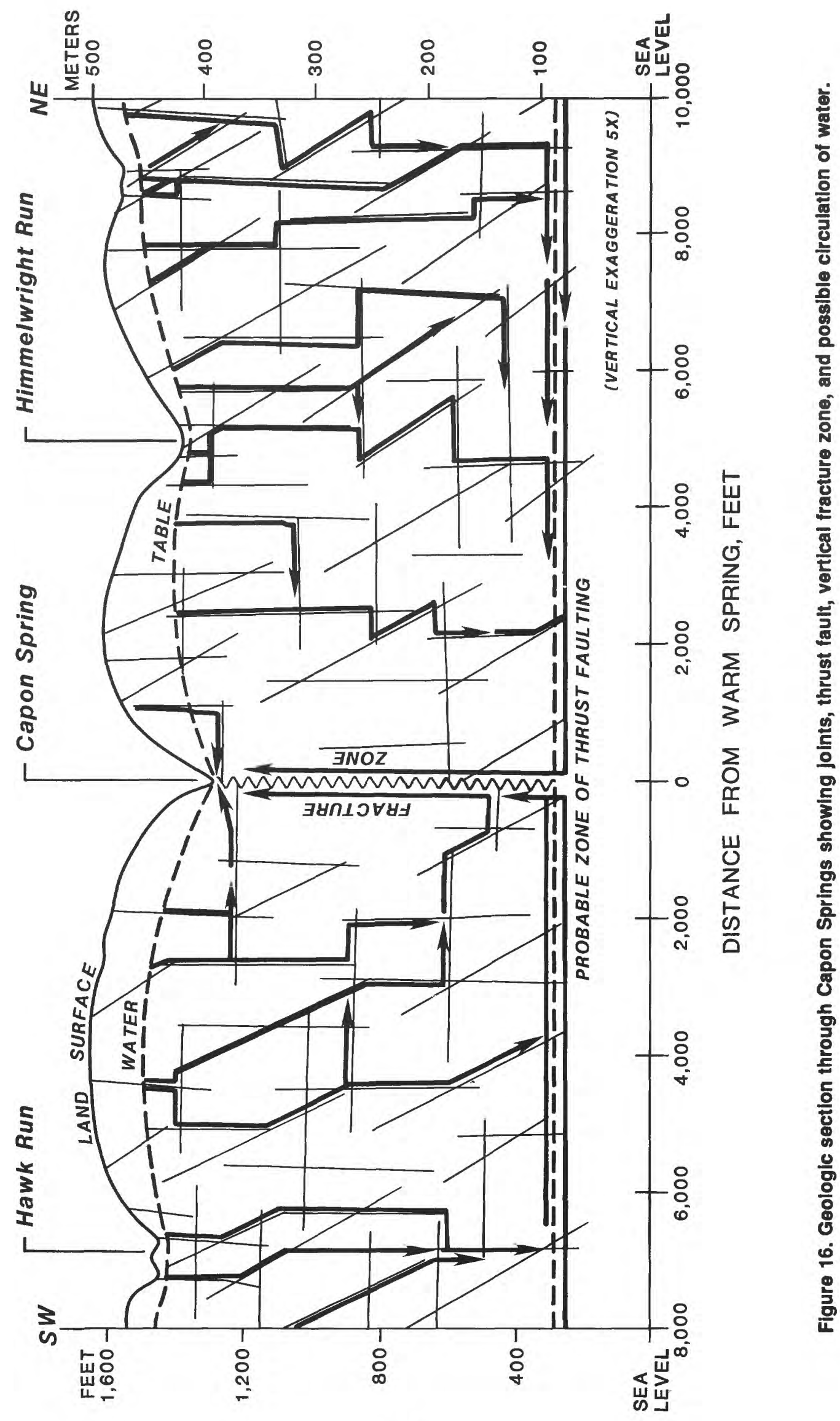


recharge areas), the rate of water movement along the thrust fault (assuming a 30-year travel time) is estimated to be about 0.70 feet per day.

A possible alternative to the thrust fault at depth explanation would be the presence of one or more tight folds about 1,000 feet deep in the Oriskany Sandstone with axes parallel to strike. Folds also would increase fracture permeability and facilitate ground-water flow toward the spring.

By use of the above relation and assuming the vertical fracture zone below the spring has a porosity of 30 percent and is 5 feet wide across the 200 feet of outcrop width, then the rate of ascent of the warm water is estimated to be 40 feet per day. If the fracture zone has a shorter effective length across the outcrop, then the rate of ascent would be faster than the above value.

The presence of this fracture zone at the spring is suggested by a N. $60^{\circ} \mathrm{W}$. lineament zone that trends from Capon Springs into the Timber Ridge Syncline (fig. 5). The gaps in the Oriskany Sandstone ridge north and south of the spring also lie along lineaments and may be points of discharge for other small springs or avenues of recharge for Capon Springs.

\section{Minnehaha, Curry, McCarty, and Dunmore Springs Areas}

Four springs have been studied in the Minnehaha Springs area of Pocahontas County: Minnehaha, Curry, McCarty, and Dunmore (fig. 1). All of these springs lie within a 14.3 mile stretch along Browns Mountain Anticlinorium, which is just west of the Allegheny Front (fig. 2). Minnehaha and Curry Springs on the east and west flanks (fig. 2) of the anticlinorium are both on or near noses of plunging anticlines in Oriskany Sandstone. Both McCarty and Dunmore Springs are on the western limb of Browns Mountain Anticlinorium and both discharge from Helderberg Group limestones. Detailed geological maps from Kulander (1968), were modified by the authors for these four spring areas (figs. 17, 18, 19, 20, 21, and 22).

Three geologic sections through Browns Mountain Anticlinorium (figs. 18, 20, and 22) illustrate its structure. They also show structural changes from southwest to northeast as the structure plunges northeast. Figure 23 shows the "Little Arch" anticline (Devil's Backbone) in the Tuscarora Sandstone, which is typical of small, low-amplitude folds in the anticlinorium.

Lineaments detected by using SLAR images of the Minnehaha Springs area are shown in figure 6 . The broad northwest maxima for lineaments does not correspond to the northwest maxima for systematic fracture (fig. 7). Likewise, there is poor correlation between the northeast maxima for lineaments and the northeast maxima for fracture trends.

Systematic fracture orientations have been measured in a variety of rock types in this area. The nearly horizontal Silurian Age Tuscarora Sandstone, which crops out in the core of Browns Mountain Anticlinorium, shows excellent fractures (fig. 24). On the limbs of the anticlinorium, fractures in the Oriskany Sandstone (fig. 25), in the limestones in the Helderberg Group (fig. 26), and in the Marcellus Shale (fig. 27) show the same northeast and northwest azimuths. This indicates a fracture signature that persists in both the Silurian and Devonian rocks.

Minnehaha and Curry springs discharge from the Oriskany Sandstone at the contact with the overlying Marcellus Shale (shown as Du on figs. 17 and 18), whereas Dunmore and McCarty springs discharge from the limestones in the Helderberg Group (figs. 19, 21). Most of the water discharging at these springs probably enters the Oriskany Sandstone outcrop and flows downdip and down plunge to depth in the Oriskany before moving upward to the springs. Backthrust faults may control the depth of circulation to the springs. Two backthrust faults have been mapped in the Curry and Minnehaha Springs area (Kulander and others, 1986); one is south of Minnehaha Springs along the east flank of the Browns Mountain Anticlinorium; the other is about 2 miles west of Minnehaha Springs and 0.1 mile east of Curry Springs. Upward migration of water probably occurs along highly fractured, nearly-vertical permeable zones, as suggested by lineaments at or near each spring (fig. 6). The chemistry of the water 


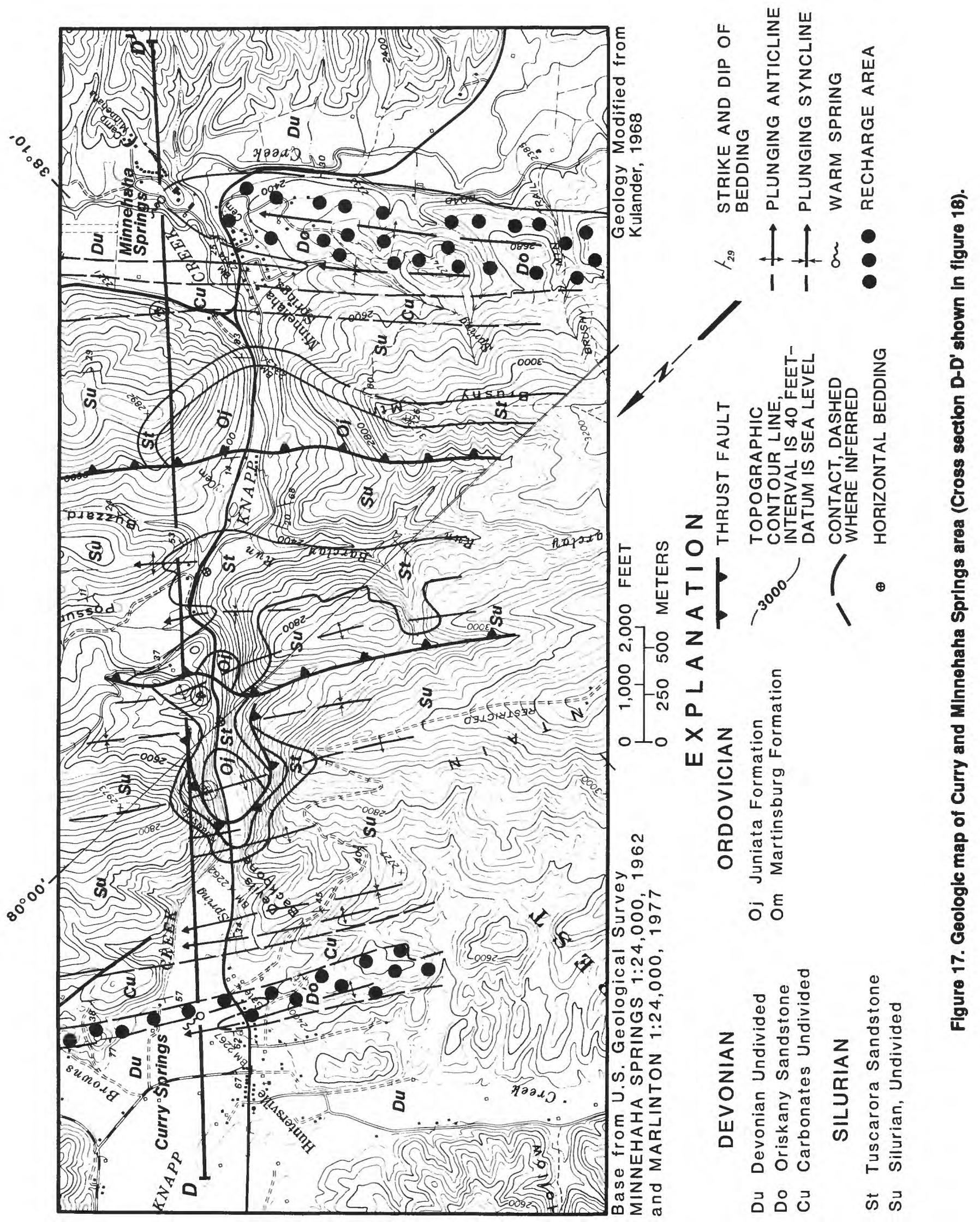




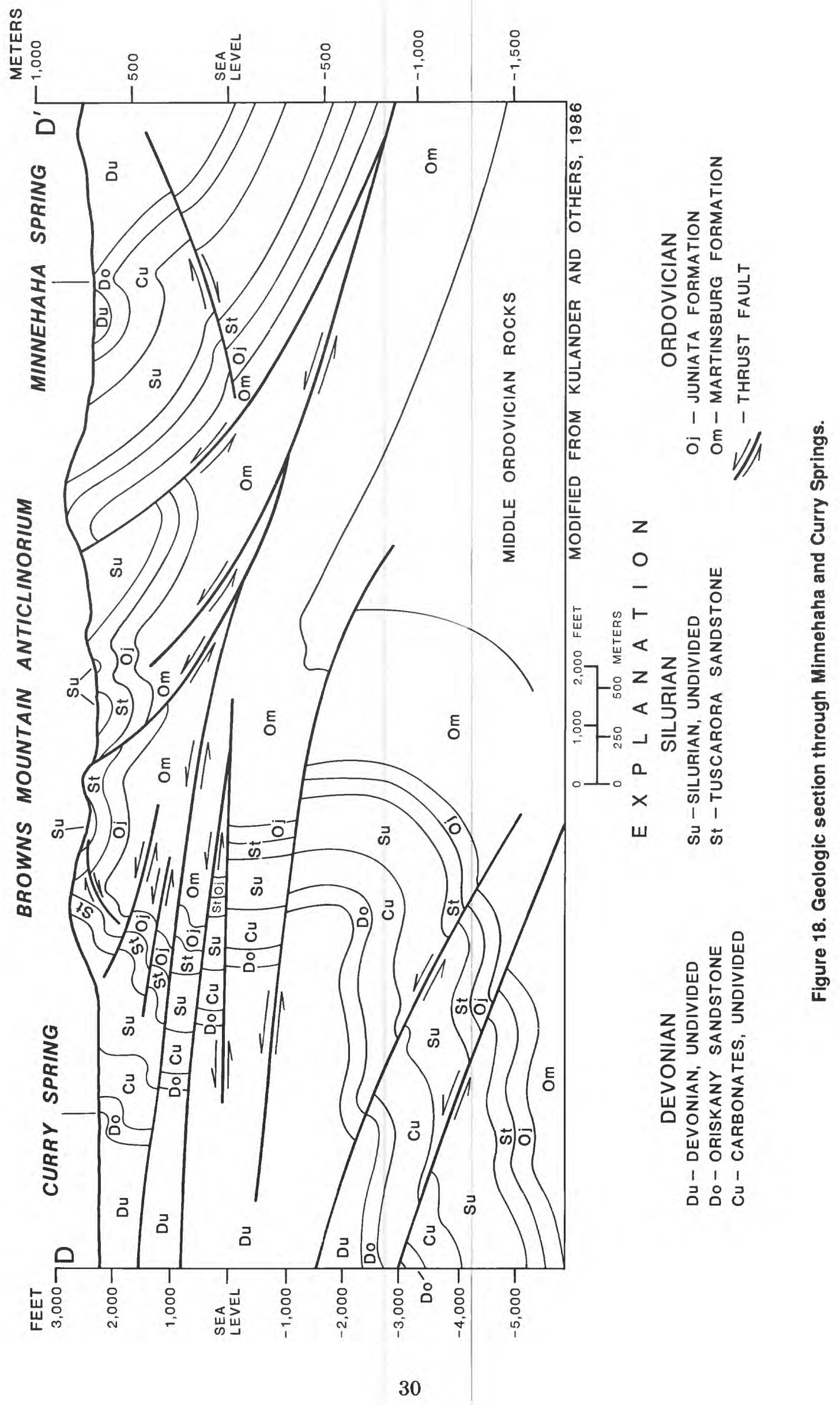




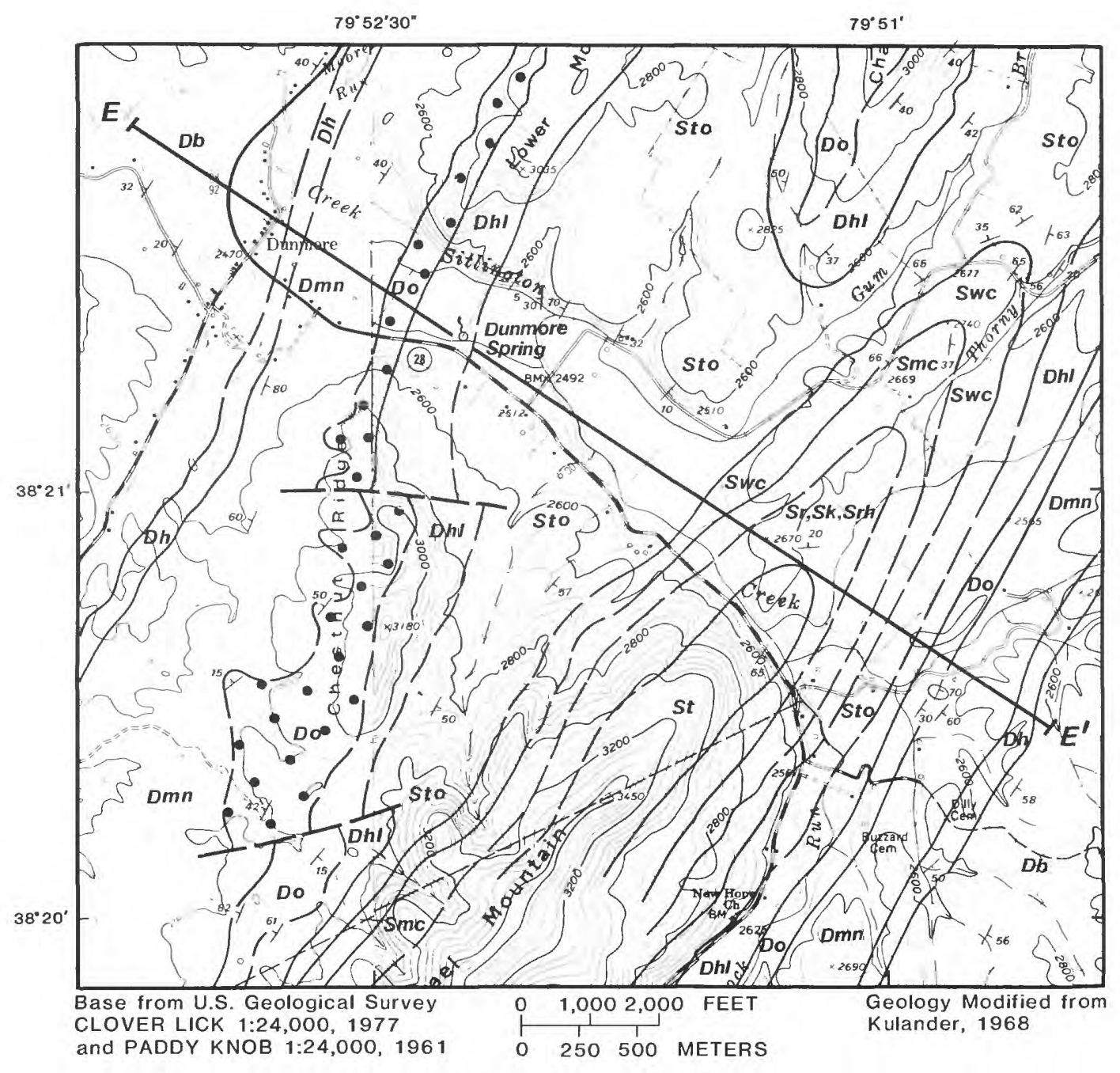

\section{DEVONIAN}

$\mathrm{Db}$ Brallier Formation

Dh Harrell Shale

Dmt Mahantango Formation

Dmn Marcellus-Needmore Shale

Do Oriskany Sandstone

Dhl Helderburg Group

\section{EXPLAN A T ION}

\section{SILURIAN}

Sto Tonoloway Limestone Swc Wills Creek Formation

$\mathrm{Sb}$ Bloomsburg Formation Smc McKenzie Formation

$\mathrm{Sr}$ Rochester Shale

Sk Keefer Sandstone

Srh Rosehill Formation

St Tuscarora Sandstone

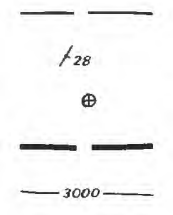

$\sim$
CONTACT, DASHED WHERE INFERRED STRIKE AND DIP OF BEDDING HORIZONTAL BEDDING

THRUST FAULT

TOPOGRAPHIC CONTOUR LINE, INTERVAL IS 40 FEETDATUM IS SEA LEVEL

WARM SPRING

RECHARGE AREA

Figure 19. Geologic map of Dunmore Spring area (Cross section E-E' shown in figure 20). 


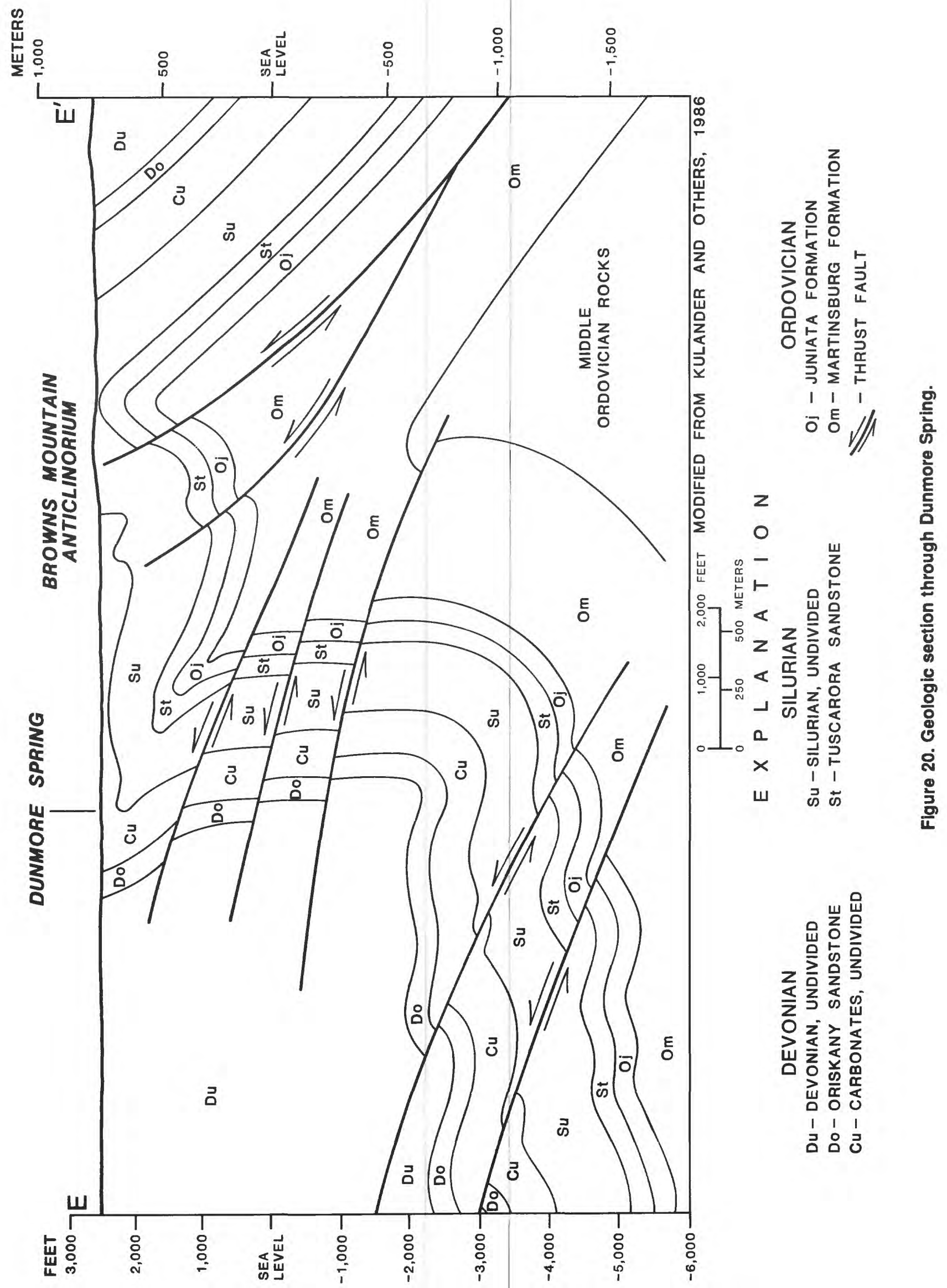




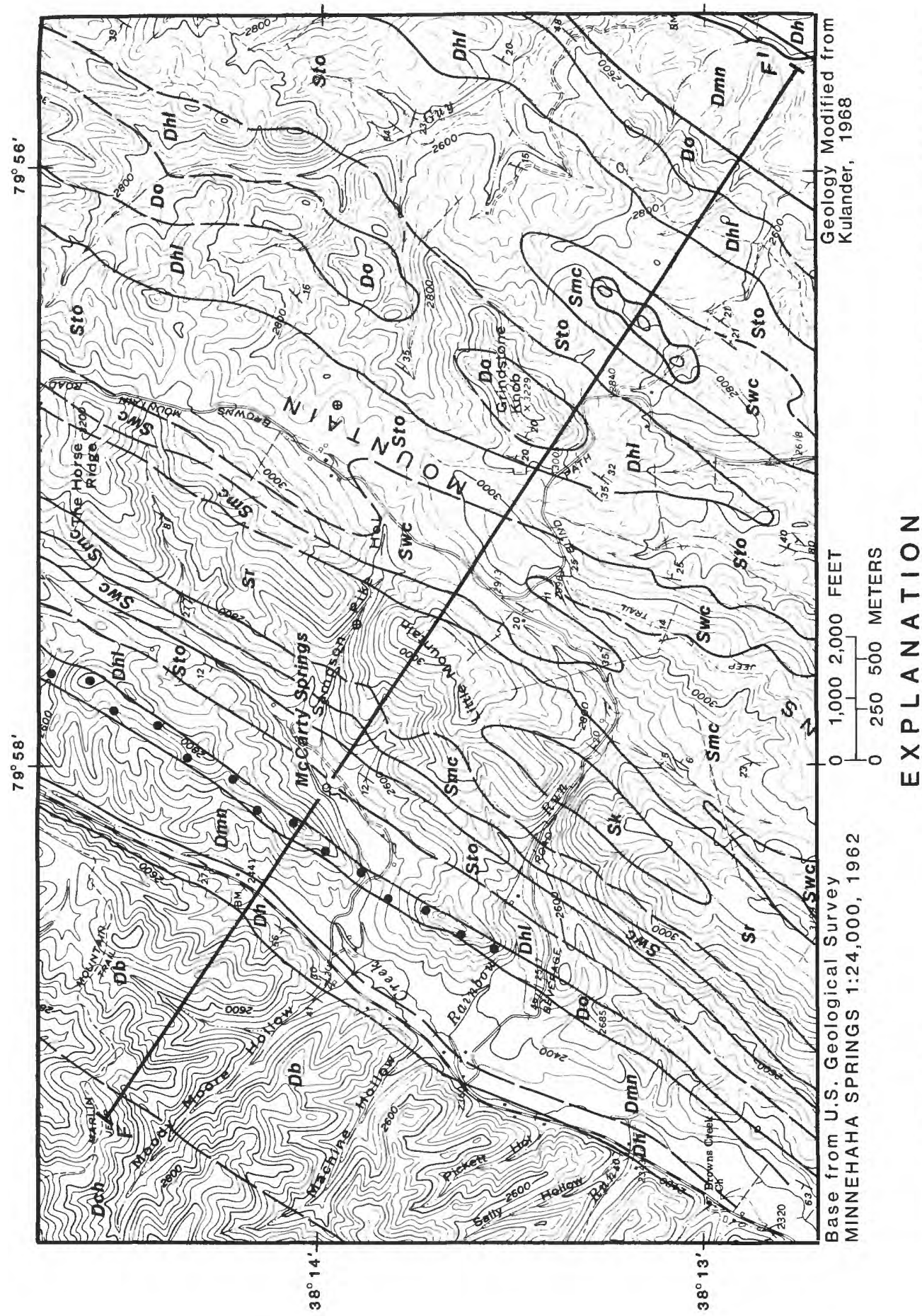

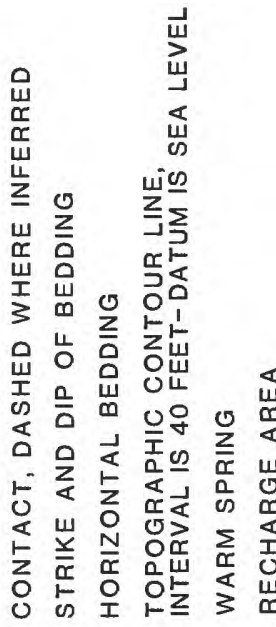

สิ

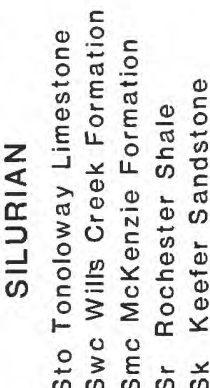

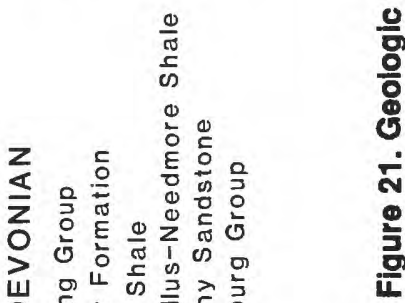


辤
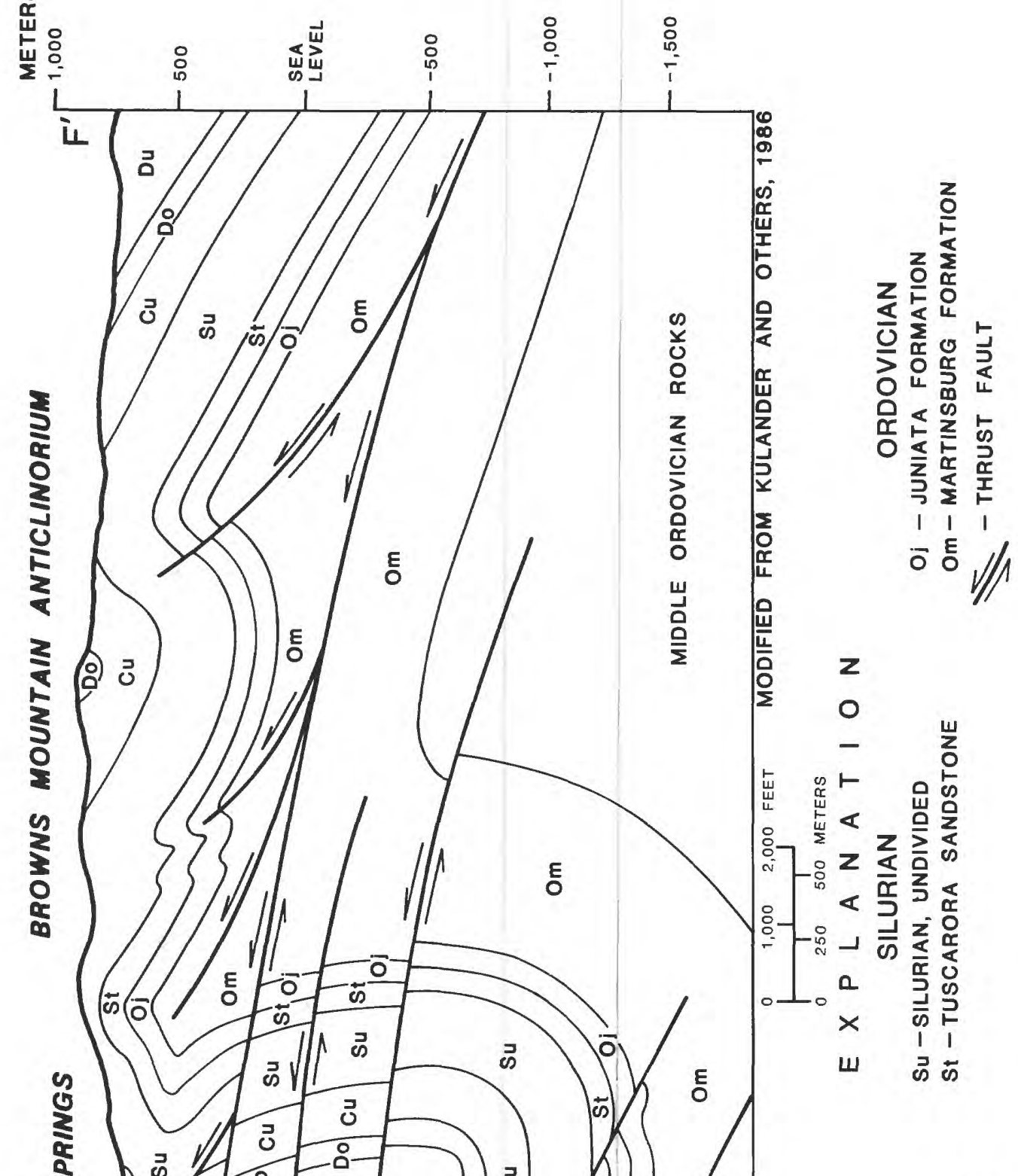

$z$

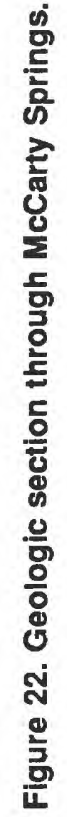

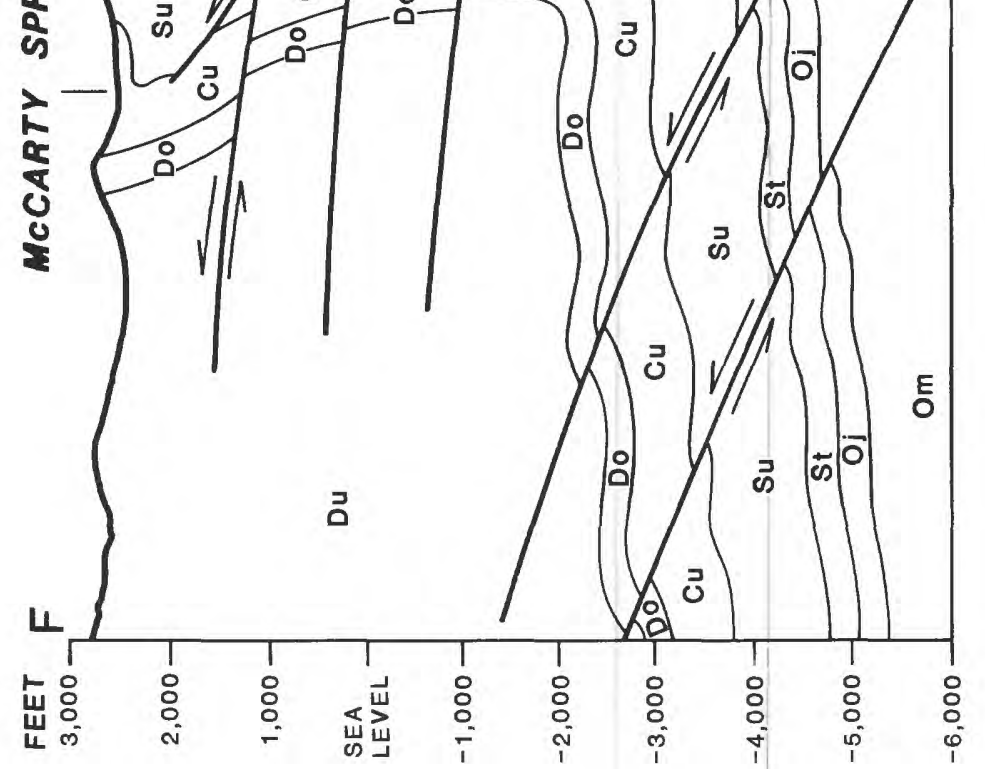

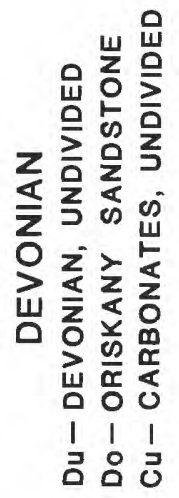




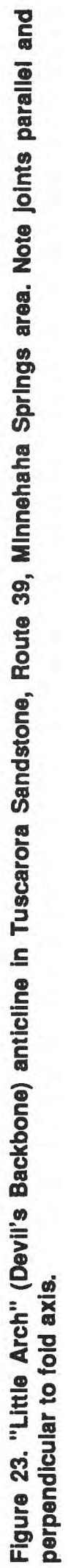


discharging at McCarty and Dunmore Springs is very similar to that of the other warm springs. This suggests that the water passes from the Oriskany Sandstone into adjacent Helderberg Group limestones as it moves upward toward the springs.

Tritium content of water from Minnehaha (1.1 TU) and Curry Springs (0.3 TU) suggests that more than 97 percent of the water is more than 30 years old. Minimum depth of circulation to the springs is estimated to be 1,500 feet and 1,080 feet, respectively. Tritium content of water from Dunmore Spring (1.5 TU) suggests that more than 96 percent of the water is more than 30 years old, whereas only 60 percent of the water at McCarty Springs is more than 30 years old (13.9 TU). High concentrations of dissolved solids in the water from McCarty Springs suggest a greater contribution of water from limestone than is found in Dunmore Spring. Minimum depth of circulation is estimated to be 985 feet at Dunmore Spring and 1,130 feet at McCarty Spring. 


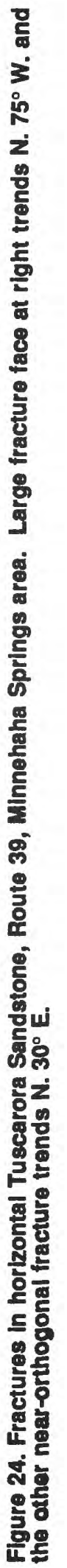




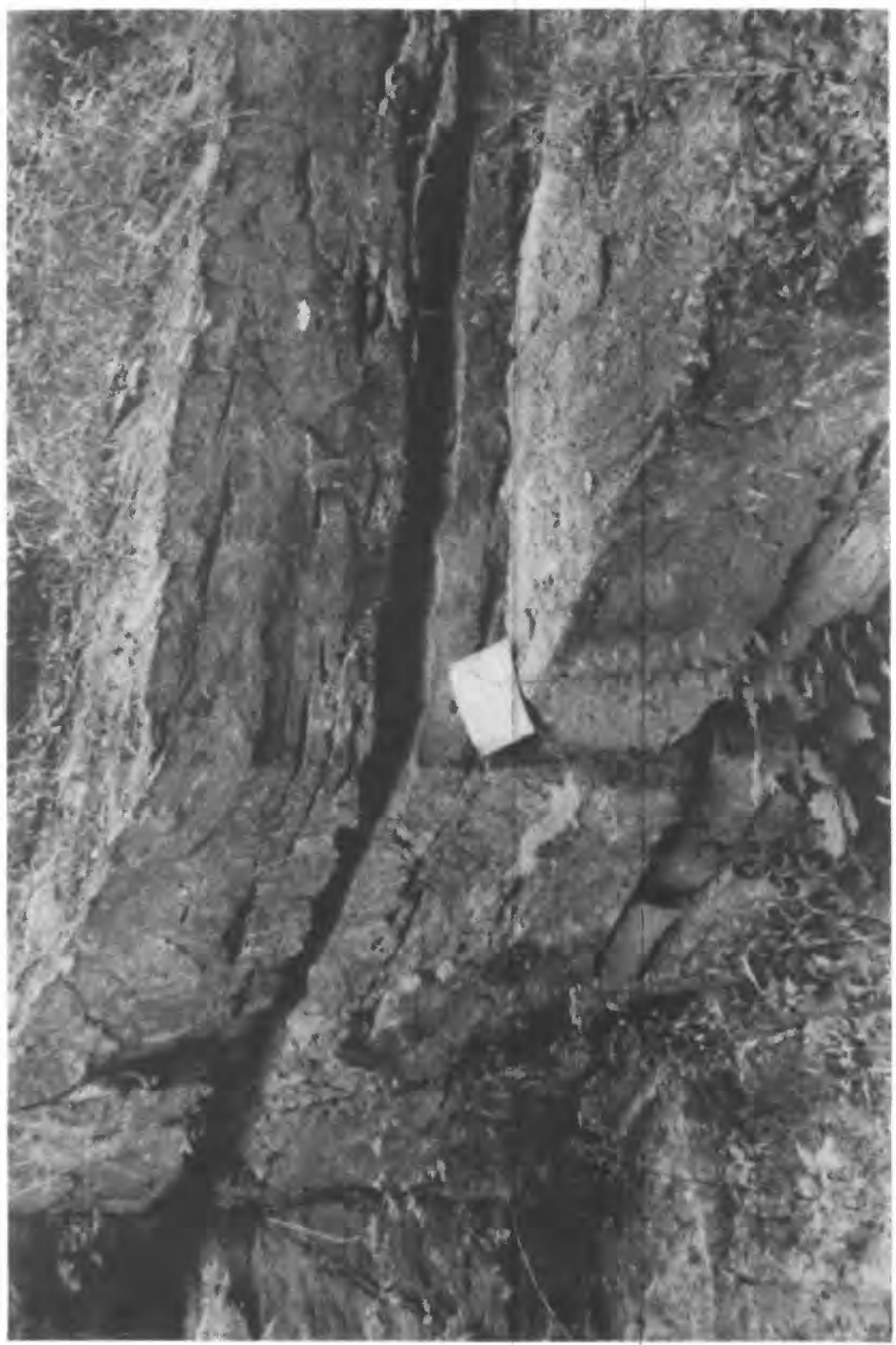



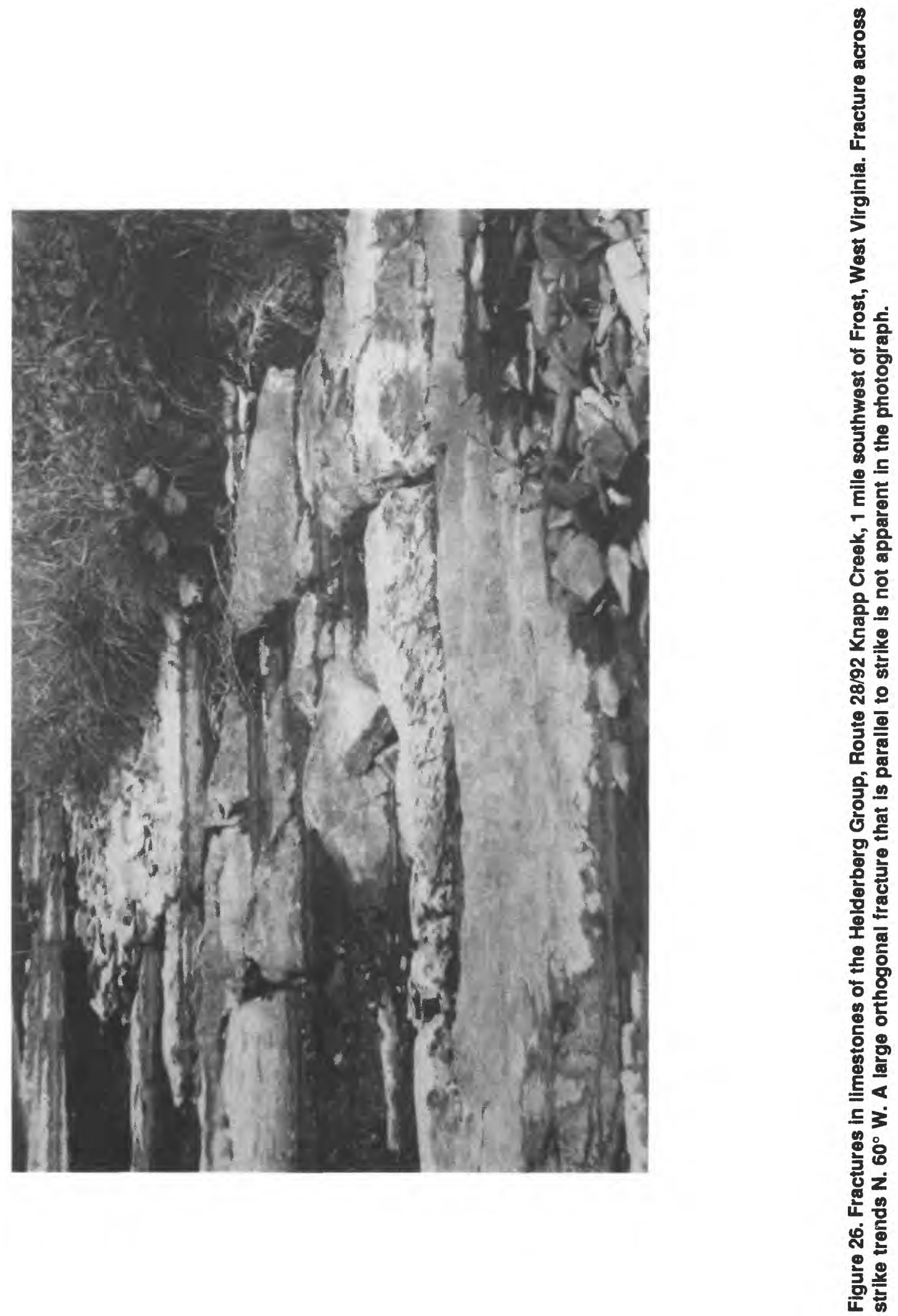

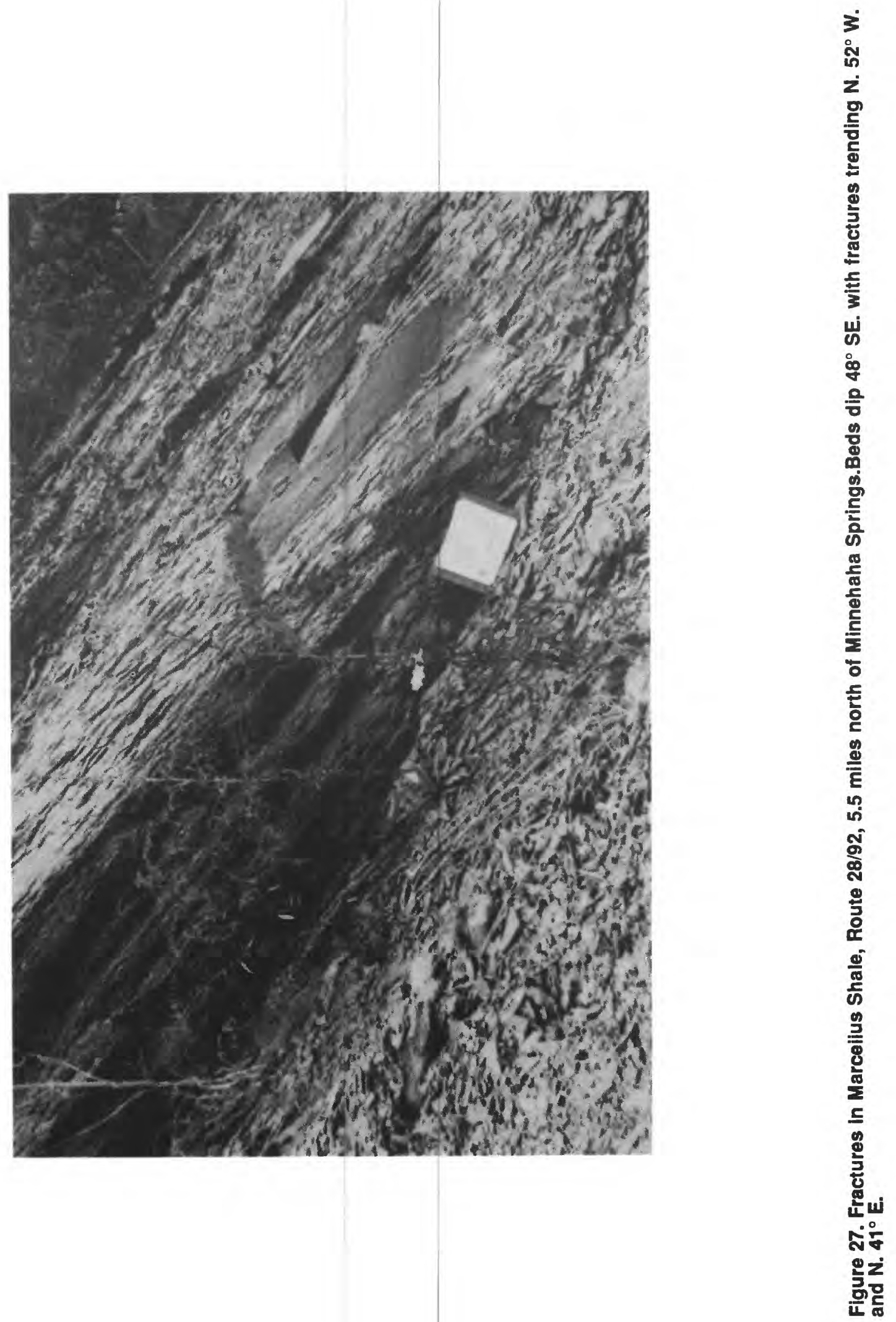


\section{SUMMARY AND CONCLUSIONS}

1. Side-looking airborne radar images show more lineaments and have better resolution than Landsat images. They also provide more information on topography, geology, and geologic structure than do Landsat images.

2. In West Virginia, SLAR lineaments generally trend northwest and northeast; however, these trends are not the same as those for systematic fractures. This lack of correlation suggests that, although SLAR lineaments probably reflect fracture zones, individual fractures need not trend parallel to the lineaments.

3. Warm springs cannot be detected on SLAR images. However, lineaments detected on the images and used in conjunction with geologic maps and a knowledge of hydrology can indicate potential areas where deep circulation may be occurring.

4. In eastern West Virginia, warm springs discharge from the Oriskany Sandstone and from the limestones of the Helderberg Group.

5. In eastern West Virginia, warm springs generally are confined to anticlinoria, because these structures expose the Oriskany Sandstone from which most of the warm springs discharge.

6. Water warmed at depth rises rapidly to warm springs through highly permeable zones. As a result, heat loss to surrounding rocks is minimized.

7. Tritium analyses indicate that 60 to 98 percent of the water from the eight warm springs investigated is more than 30 years old.

8. The estimated depth of water circulation for the eight warm springs ranged from $\mathbf{7 4 0}$ to 1,800 feet.

9. Deep circulation to other warm or cool springs associated with Oriskany Sandstone in valley areas located on major anticlinoria in eastern West Virginia may occur. 


\section{REFERENCES}

Butts, Charles, and Edmundson, R. S., 1966, Geology and mineral resources of Frederick County: Virginia Mineral Resources, Bulletin 80, 142 p.

Cardwell, D. H., Erwin, R. B., and Woodward, H. P., compilers, 1968, Geologic map of West Virginia: West Virginia Geological and Economic Survey Map, scale 1:250,000.

Clark, W. E., Chisholm, J. L., and Frye, P. M., 1976, Water resources of the Upper New River basin, West Virginia: West Virginia Geological and Economic Survey, River Basin Bulletin $4,87 \mathrm{p}$.

Dean, S. L., Kulander, B. R., Lessing, Peter, 1985, Geology of the Capon Springs, Mountain Falls, Wardensville, Woodstock and Yellow Springs Quadrangles, Hampshire and Hardy Counties, West Virginia: West Virginia Geological and Economic Survey Map-WV26.

Dyckes, J. A., 1964, Geology of the southwest part of Wardensville 15-minute quadrangle: Morgantown, West Virginia, West Virginia University, unpublished MS thesis, 31 p.

Erskine, H. M., 1948, Principal springs of West Virginia: Conservation Commission of West Virginia Publication, $50 \mathrm{p}$.

Friel, E. A., Wilmoth, B. M., Ward, P. E., and Wark, J. W., 1967, Water resources of the Monongahela River basin, West Virginia: West Virginia Department of Natural Resources and West Virginia Geological and Economic Survey, 118 p.

Geiser, P. A., 1970, Deformation of the Bloomsburg Formation in the Cacapon Mountain anticline, Hancock, Maryland: Baltimore, Maryland, Johns Hopkins University, Ph.D dissertation, $188 \mathrm{p}$.

Grimsley, G. P., 1916, County reports-Jefferson, Berkeley, and Morgan Counties: West Virginia Geological Survey, 644 p.

Hobba, W. A., Jr., 1985, Water in Hardy, Hampshire, and western Morgan Counties, West Virginia: West Virginia Geological and Economic Survey Environmental Geology Bulletin EGB-19.

Hobba, W. A., Jr., Fisher, D. W., Pearson, F. J., Jr., and Chemerys, J. C., 1979, Hydrology and geochemistry of thermal springs of the Appalachians: U.S. Geological Survey Professional Paper 1044-E, $36 \mathrm{p}$.

Hobba, W. A., Jr., Friel, E. A., and Chisholm, J. L., 1972, Water resources of the Potomac River basin, West Virginia: West Virginia Geological and Economic Survey, River Basin Bulletin 3, $110 \mathrm{p}$.

Kulander, B. R., 1968, Structural analysis of Brown's Mountain anticline in West Virginia: Morgantown, West Virginia, West Virginia University, unpublished Ph.D. dissertation, $174 \mathrm{p}$. 
Kulander, B. R., and Dean, S. L., 1972, Gravity and structures across Browns Mountain, Wills Mountain, and Warm Springs anticlines-gravity study of the folded plateau, West Virginia, Virginia, and Maryland, in Lessing, Peter, ed., Appalachian structures: origin, evolution, and possible potential for new exploration frontiers-a seminar: West Virginia University and West Virginia Geological and Economic Survey, p. 141-180.

1978, Gravity, magnetics, and structure of the Allegheny Plateau/western Valley and Ridge in West Virginia and adjacent states: West Virginia Geological and Economic Survey Report of Investigations RI 27, 91 p.

1983, Thrust plate structural frame work in the central and southern Appalachians, abstract: Geological Society of America, Abstract with Program, V. 15, No. 6, p. 620.

Kulander, B. R., and Dean, S. L., 1986, Structure and tectonics of central and southern Appalachian Valley and Ridge and Plateau provinces, West Virginia and Virginia: American Association of Petroleum Geologist Bulletin, V. 70, pp. 1674-1684.

Kulander, B. R., Dean, S. L., Hobba, W. A., Jr., and Lessing, Peter, 1984, Geological control on warm springs in eastern West Virginia: Geological Society of America, Abstract with Program, V. 16, No. 3, p. 151.

Kulander, B. R., Dean, S. L., and Lessing, Peter, 1986, Browns Mountain Anticlinorium, West Virginia: Geological Society of America, Centennial Field Guide, V. 6., pp. 101-104.

Martin, R. H., 1964, Geology of the Great Cacapon, West Virginia-Maryland quadrangle: Morgantown, West Virginia, West Virginia University, unpublished MS thesis, 34 p.

Minke, J. G., 1964, Geology of the Hancock and Stotlers Crossroads quadrangles in West Virginia: Morgantown, West Virginia, West Virginia University, unpublished MS thesis, $42 \mathrm{p}$.

Moore, G. K, and Sheehan, C. A., 1981, Evaluation of radar imagery for geologic and cartographic applications: U.S. Geological Survey, Open-File Report 81-1358, 37 p.

Nock, H. M., 1968, Geology of the Capon Bridge, West Virginia-Virginia quadrangle: Morgantown, W. Va., West Virginia University, unpublished MS thesis, $43 \mathrm{p}$.

Pascucci, R. F., Smith, A. F., and Pearson, J. E., 1981, Determination of the contribution of side-looking airborne radar to structural geologic mapping: Autometric Incorporated, 61 p., 6 appendices.

Price, P. H., 1929, County reports-Pocahontas County: West Virginia Geological Survey, 531 p.

Price, P. H., McCue, J. B., and Hoskins, H. A., 1936, Springs of West Virginia: West Virginia Geological Survey, V. 6, 146 p.

Reynolds, J. H., 1979, Landsat linear features of West Virginia: 1:250,000 scale, West Virginia Geological and Economic Survey, Map 7A and B. 
Rogers, W. B., 1843, On the connection of thermal springs in Virginia with anticlinal axes and faults: Association of American Geologists and Report of 1st, 2nd, and 3rd meetings 1840-1842, p. 323-347.

Tilton, J. L., Prouty, W. F., Tucker, R. C., and Price, P. H., 1927, County reports-Hampshire and Hardy counties: West Virginia Geological Survey, 624 p.

Trainer, F. W., and Ellison, R. L., 1967, Fracture traces in the Shenandoah Valley, Virginia: Photogrammetric Engineering, V. 33, No. 2, p. 190-199.

Waring, G. A., 1965, Thermal springs of the United States and other countries of the world-a summary: U.S. Geological Survey Professional Paper 492, 383 p.

Young, R. S., and Rader, E. K., 1974, Geology of the Woodstock, Wolf Gap, Conicville, and Edinburg quadrangles, Virginia: Virginia Division of Mineral Resources Report of Investigations R I 35, 69 p. 